\title{
Geochemistry and Radioactivity of Mineralized Pegmatite from Abu Rusheid Area, South Eastern Desert, Egypt
}

\author{
Ablah Ahmad Ragab \\ Nuclear Materials Authority of Egypt, Kattamiya, Cairo
}

Received: 24/ 01/2010

Accepted: 27/ 06/2010

\begin{abstract}
The mineralized pegmatite of Abu-Rusheid area, S. Eastern Desert, has quartz core and feldspars and mica margins. This pegamtite was analyzed by the Inductively Coupled Plasma-Mass Spectrometry (ICP-MS) to determine the content of the major and trace elements including the rare earth elements (REE). The mineralized pegmatite vein trends NNW-SSE with dip of about 10$30^{\circ}$ due WSW. It is emplaced parallel to foliation and banding of the cataclastic country rocks. The studied pegmatite is classified as rare metals-enriched and shows a zonal distribution from the barren core to the mineralized wall-zone in the metals; Nb, Ta, Zr, Hf, Th, U, Y and $\mathrm{Ga}$. The main carriers of the trace metals are zircon, rutile, columbitetantalite, samarskite and other REE and Th-U minerals. Cassiterite, chlorite, deep violet fluorite, calcite, goethite, hematite, pyrite, magnetite, zinnwaldite, and phlogobite, are the main accessory minerals. The studied pegmatite is highly differentiated, NYF-type and characterized by high $\mathrm{FeO} / \mathrm{MgO}$ ratio with high concentration of $\mathrm{Nb}, \mathrm{Y}, \mathrm{Zr}, \mathrm{Th}, \mathrm{U}, \mathrm{REE}$ (except $\mathrm{Eu}$ ), and Ga. It is derived from Fenriched proterozoic crustal source depleted in Cs, B and P. The rock is peraluminous and highly fractionated and had been affected by hydrothermal alteration. The pegmatite displays clear M-type tetrad effect of the REE. The calculated tetrad effect in the pegmatite of Abu-Rusheid demonstrates clear tendency towards the ratios of the common isovalents such as $\mathrm{Zr} / \mathrm{Hf}, \mathrm{Nb} / \mathrm{Ta}$ and $\mathrm{Y} / \mathrm{Ho}$. However, the tetrad effect seems not to be mutual with the content of $\mathrm{Na}_{2} \mathrm{O}$ and $\mathrm{Rb} / \mathrm{Sr}$. The absence of coherence between tetrad effect and soda content may indicate insignificant role of the Na-metasomatism in developing the tetrad effect. The pegmatite has a prominent negative $\mathrm{Eu}$ anomaly and excessively low $\mathrm{K} / \mathrm{Rb}$ ratio. The radioactivity of the studied pegmatite is related to a) uranium mineral (autunite), b) thorium minerals (thorite, thorianite and uranothorite) and c) accessories minerals (zircon, allanite, xenotime, monazite, fluorite,
\end{abstract}


columbite and samarskite). The potential anomalous radioactivity in the pegmatite of Abu Rusheid is attributed to both magmatic and hydrothermal processes.

\section{Introduction}

Pegmatites have come to occupy a place of increasing significance since they constitute the source of many important minor and trace elements used by present day technology, e.g., lithium, cesium, beryllium, scandium, niobium, tantalum, tin, rare earths. In addition to feldspar, mica, quartz and large variety of highly priced colored gem minerals.

Granitic magmas that evolve by crystal fractionation merge toward similar composition at the thermal minimum in their quartz - albite orthoclase $-\mathrm{H}_{2} \mathrm{O}$ system and their subsequent evaluation is strongly influenced by the presence of volatile components (e.g. F, B, Li, P) that can radically influence melt structure, crystal-liquid and melt-vapor equilibrium in evolving magma system (London 1992; and Diapak et al., 2006).

Rapid advances have been made in the establishment of petrogenetic models for rare metal pegmatites in recent years based on a combination of field and laboratory studies. The broad scale characteristics of pegmatite fields, together with detailed work on individual pegmatite types, have enabled the development of a comprehensive classification of pegmatite and predictive models for the assessment of pegmatite (Cerny, 1991b; Morteani et al., 1995, and Abd El-Naby and Saleh 2003, Sosa et al., 2002, Surour et al., 2004; Zagorsky and Peretyazhko, 2006, Abd El Wahed, et al., 2007 and Saleh et al., 2007). The mechanism(s) by which the magma evolve to extreme chemical composition is of special interest because this residual magma may be: (1) inject into the surrounding rocks to crystallize as rare metal pegmatite, (2) to crystallize in-situ as granites containing primary rare metal minerals; and (3) to partition ore elements into magmatic hydrothermal fluids with precipitation during subsequent pervasive alteration, particularly in tin-bearing system.

The geochemical behavior of the rare earth elements (REE) has been studied extensively because this group of elements provide geochemical indicators that can be used to constrain the evolution of magmatic and hydrothermal systems (e.g. Molloer and Muecke, 1984; 
Masuda and Akagi, 1989; Bau, 1996, 1997; Moller, 1998; Irber 1999; and Monecke et al., 2000). It has shown that variation in the geochemical behavior of the REE primarily result from difference in their ionic radii as well as variations in valence state $\left(\mathrm{Ce}^{3+}\right.$ and $\mathrm{Ce}^{4+}, \mathrm{Eu}^{2+}$ and $\left.\mathrm{Eu}^{3+}\right) . \mathrm{An}$ additional feature that potentially influences the distribution of the REE in some geological environments is the lanthanide tetrad effect (Masuda et al., 1987; Kawabe, 1995; Bau, 1996; Irber, 1999, and Monecke et al., 2002). The tetrad effect of highly evolved peraluminous magmas results from melt/fluid interaction (Bau, 1997; and Irber, 1999).

\section{Geologic Setting}

The tectono-stratigraphic sequence of the Precambrian rock units of Abu Rusheid area (Fig. 1) are arranged in the following order according to Ibrahim et al. (2006):

(1) Metagabbro

(2) Ophiolitic mélange (consisting of ultramafic rocks and layered metagabbros set in metasediments matrix),

(3) Cataclastic rocks,

(4) Granitic rocks

(5) Lamprophyre dykes

(6) Pegmatite.

The present work is concerned with the complex pegmatite filling the foliation and banding in the cataclastic rocks. The geology, geochemistry and mineralogy of the cataclastic rocks at Abu Rusheid area have attracted the attention of many authors. Some workers (e.g. Hassan, 1973; Abdel Monem and Hurley, 1979, Hilmy et al., 1990; and Abdel-Naby and Frisch, 2006) consider Abu Rusheid rocks as psammitic gneisses, whereas others considered these rocks as cataclastic rocks composed mainly of protomylonites, mylonites, ultramylonites and quartzites with gradational contacts (Ibrahim et al., 2006, 2007 a,b,c; and El-Mahdy, 2008).

The cataclastic rocks are highly sheared, foliated, banded and folded especially at their contacts with the ophiolitic mélange. The cataclastic rocks at Abu Rusheid area show one of the high radioactive zones in the south Eastern Desert of Egypt. They also contain high contents of $\mathrm{Nb}, \mathrm{Ta}, \mathrm{Sn}, \mathrm{Pb}$ and $\mathrm{Zr}$. They are intersected by two sets of 
shear zones (NNW-SSE \& ENE-WSW). The Lamprophyre dykes are emplaced along the two shear zones and bearing mineralization. The NNW-SSE lamprophyre dykes host $\mathrm{Zn}, \mathrm{U}, \mathrm{Cu}, \mathrm{REE}$ and $\mathrm{Sn}$ mineralization, whereas those trending ENE-WSW lamprophyre dykes contain Nb-Ta, Th, U and Zn minerals (Ibrahim et al., 2006, 2007 a,b,c; and El-Mahdy, 2008).
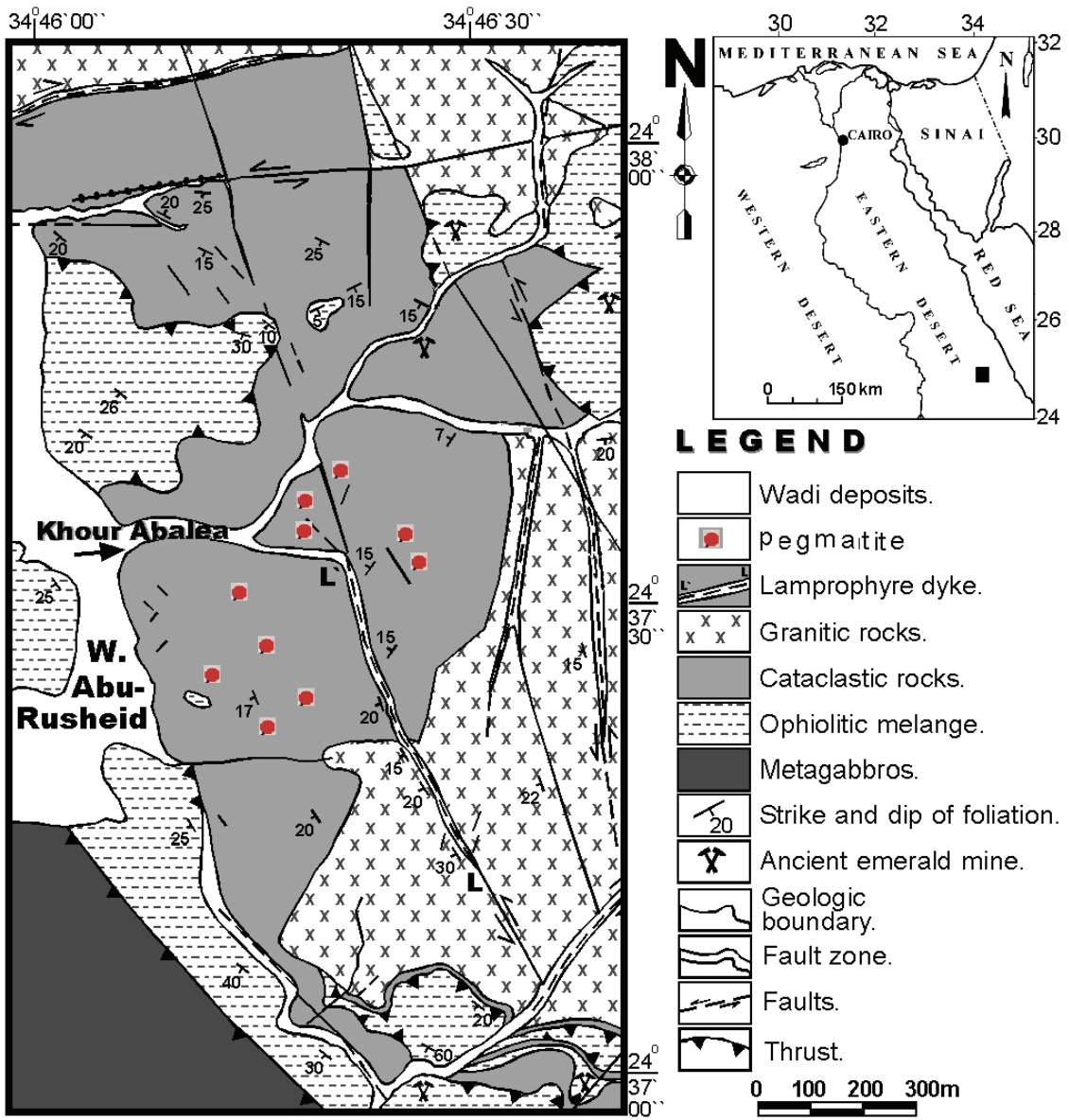

LEGEN D

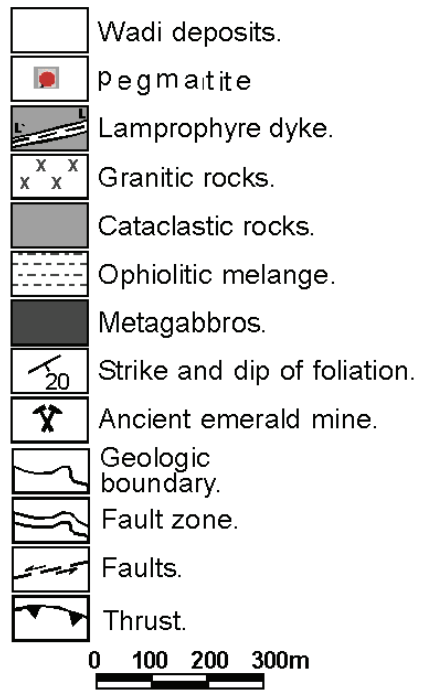

Fig. 1. Geologic map of Abu Rusheid area, southeastern Desert, Egypt (after Ibrahim et al., 2006).

Two types of pegmatites were reported in Abu Rusheid area; a) mineralized pegmatites (NNW-SSE and dip 10-30 due WSW) emplaced parallel to the foliation and banding of cataclastic rocks and b) barren pegmatites (NE-SW and dip nearly vertical) cut the cataclastic rocks. The mineralized pegmatites vary from $20 \mathrm{~cm}$ to $50 \mathrm{~cm}$ in width, scattered in 
the cataclastic rocks except quartzites and sometimes show boudins structure especially at the intensively tectonic parts (Fig. 2).

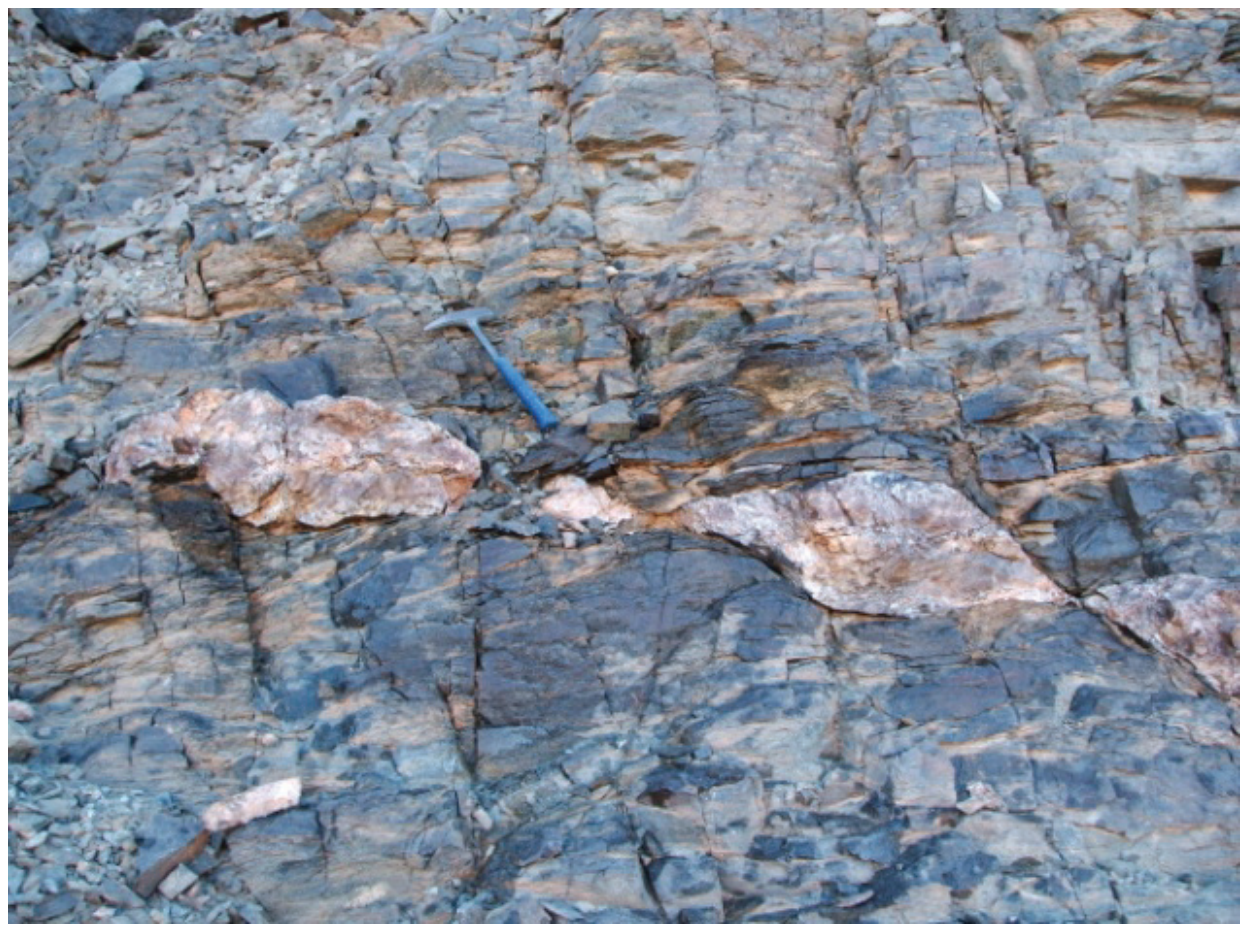

Fig. 2. Pegmatite boudins parallel to the banding of the cataclastic rocks, Abu Rusheid area.

\section{Experimental Work}

The present study aims to study the mineralogy, behavior of REE, trace elements and radioactivity of the pegmatite in Abu Rusheid area, south Eastern Desert, Egypt. 10 samples were collected to represent the complex composition of the pegmatite including its core and wall. Collaborative techniques have been used to quantify the mineral and chemical composition of the collected samples. The used experimental techniques involve; X-Ray Diffraction (XRD), Scanning Electron Microscope (SEM) attached with Dispersive Microanalyzer (EDX) and Inductively Coupled Plasma-Mass Spectrometry (ICP-MS). Ten samples representing the mineralized pegmatite were analyzed for major oxides, trace and rare earth elements by ICP-MS at AMCE analytical labs, Vancouver, Canada (Table 1). 


\section{Petrography and Mineralogy}

The mineralized pegmatites of Abu Rusheid area are usually of the zoned type. The zonation starts with quartz at the core (smoky to milky color) associated with mica followed by alkali feldspars at the margins. The feldspars vary in color from pink to milky and in composition from $\mathrm{K}$-feldspar to Na-feldspar. Sometimes intercalations of both types are common due to albitization of K-feldspars. The mineralized pegmatites are characterized by cavities and vugs. These vugs are common in quartz and decrease in alkali feldspars and could be considered as physical traps for any incoming later mineralization. The wall-zones of the mineralized pegmatites are mainly composed of amazonite which is a green variety of microcline feldspar found in association with quartz, orthoclase, albite and biotite. Fluorite, xenotime, allanite, zircon, radial uranyl mineralization and opaques are accessories. Kaolinite, sericite, chlorite, cordierite and muscovite are secondary minerals (Fig. 3a-f). The occurrence of cordierite is a result of contact metamorphism between the ophiolitic mélange and cataclastic rocks.

In the studied pegmatite, the presence of albitization, chloritization, fluoritization and silicification are mainly due to the effect of hydrothermal solution have also been observed.

The mineralogical investigation of the pegmatite was performed on whole rock samples and separated mineral grains by petrographic microscope, Electron-Scanning Microscope (SEM) supported by EDX and X-Ray Diffraction analysis (XRD).

\section{Uranium Minerals}

Autunite which is hydrated phosphate containing hexavalent uranium is detected in the present work. The crystals have subparrallel growth and grading into fan-like aggregates (Fig. 3d). It is pale yellowish green and strained brown in color. Autunite is found as an alteration product of uraninite in pegmatite at numerous places in New England, the Appalachian region and elsewhere. It is associated with quartz and muscovite. 


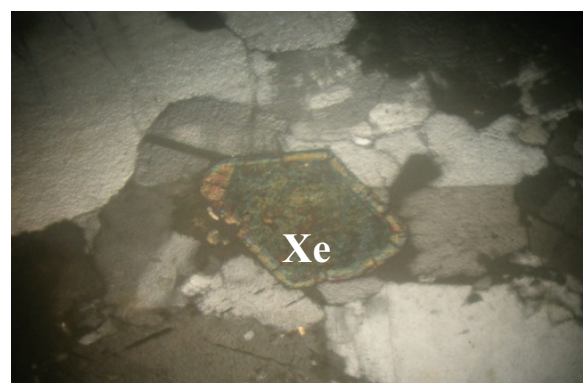

(A)

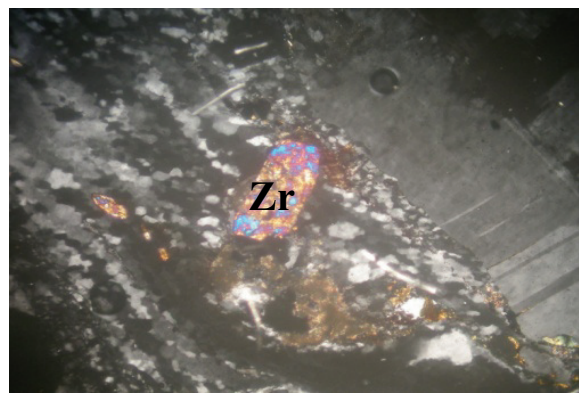

(C)

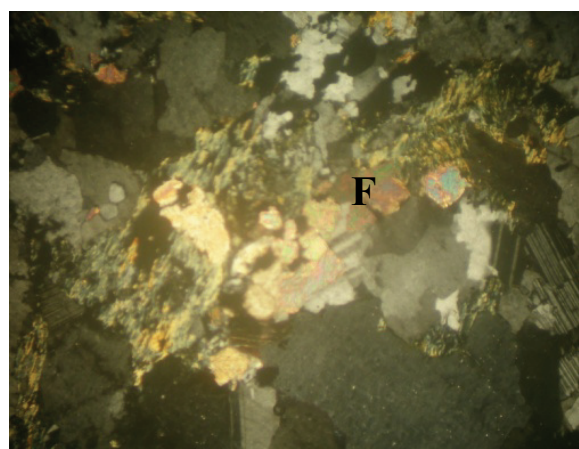

(E)

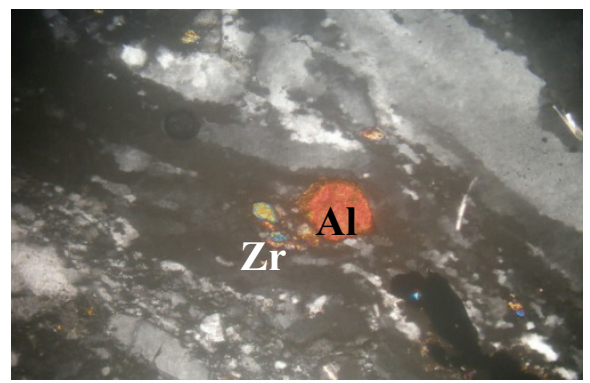

(B)

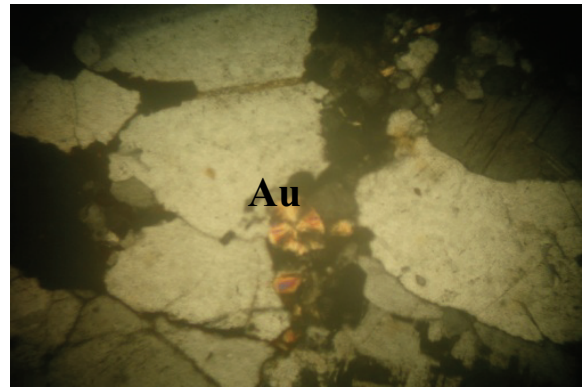

(D)

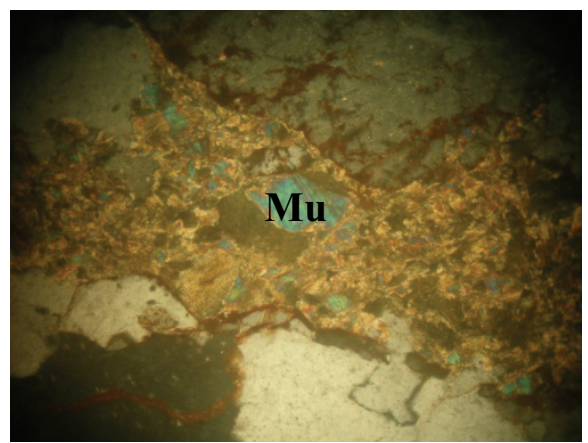

(F)

Fig. 3. Photomicrographs of the Abu-Rusheid pegmatite (C.N).

A. Xenotime crystal (Xe) surrounded by pleochroic haloes (C.N).

B. Euhedral crystal of zircon ( $\mathrm{Zr}$ ) and allanite (AI) crystals (C.N).

C. Euhedral crystal of zircon $(\mathrm{Zr})$ associated with quartz and plagioclase.

D. Fanlike aggregate crystals of autunite(Au) (C.N).

E. Secondary muscovite, chlorite of pennite type and deep violet fluorite (F).

F. Secondary muscovite (Mu) (C.N). 


\section{Thorium Minerals}

Three minerals of thorium have been identified, namely; (1) Thorianite which forms poor cleavable black crystals with submetallic luster. It is associated with zircon and thorite (Fig. 4a). Thorianite and uraninite are common in many types of pegmatites (Fig. 4b) but many LCT-type pegmatites carry it as well (Simmons et al., 2003). (2) Thorite is associated with fluorite, pyrite, zircon and iron oxides where all induce high radioactivity (Fig. 4c). Thorite is mostly of high-temperature hydrothermal origin. (3) Uranothorite in the studied pegmatite contains $39 \% \mathrm{ThO}_{2}, 16 \% \mathrm{UO}_{2}$ and $6 \% \mathrm{Y}_{2} \mathrm{O}_{3}$ with low $\mathrm{UO}_{2} / \mathrm{ThO}_{2}$ of 0.39 .


Fig. 4. BSE images and ESEM spectrum from Abu Rusheid pegmatite.
A) Uranothorite (bright)
B) Thorianite. (bright).
C) Thorite. 


\section{Cassiterite}

It is a common accessory mineral found in moderately to high evolved assemblages within a pegmatite, (Simmons et al., 2003). Cassiterite is usually associated with albitization in the studied pegmatite. It is a brown or black tetragonal mineral. The SEM analysis confirms its stoichiometric composition (Fig. 5a), which is often nearly pure $\mathrm{SnO}_{2}$. Cassiterite is also found in some contact-metasomatic deposits in close association with different sulfides, which indicates a deposition during the hydrothermal stage

\section{Columbite-Tantalite}

It is isomorphous with tantalite and appears black in color. The composition of most of the studied columbite-tantalite grains plot within the field of columbite proper - in the columbite quadrilateral diagram of Cerny et al. (1992). Wise and Cerny (1996). Columbite is in association with $\mathrm{UO}_{2}, \mathrm{ThO}_{2}, \mathrm{CaO}$ and $\mathrm{TiO}_{2}$ (Fig. 5c). Columbite-tantalite mineralization is spatially and genetically associated with post-orogenic geochemistry distinct granitoids (Tischendorf, 1977).

Columbite-tantalite of peraluminous Li-rich albite granite is constrained between $\mathrm{MnNb}_{2} \mathrm{O}_{6}$ and $\mathrm{MnTa}_{2} \mathrm{O}_{6}$. The columbite of metasomatized granites ranges in the composition between $\mathrm{FeNb}_{2} \mathrm{O}_{6}$ and $\mathrm{MnNb}_{2} \mathrm{O}_{6}$ and it is characterized by high $\mathrm{Ti}$ and $\mathrm{U}$ and low Ta content, (Abdalla et al., 1998). The SEM analysis shows its typical composition of ferocolumbite (Fig. 5b). The columbite of the studied pegmatite is associated with zircon, quartz and samarskite.

\section{Samarskite}

It is an extremely complex mixture of rare-earth elements with niobium and tantalum oxide. It is brownish-black in color and associated with feldspars, columbite and monazite. The EDX data suggest dominance of $\mathrm{Y}+\sum \mathrm{REE}(35 \%)$ and almost chondritic $\mathrm{Nb} / \mathrm{Ta}$ ratio of 14 . The empirical formula of the homogenous variety of samarskite in the study area is calculated by Ibrahim (1999) to be (Y, $\left.\mathrm{Fe}^{2+}, \mathrm{U}, \mathrm{REE}\right)(\mathrm{Nb}, \mathrm{Ta})$ $\mathrm{O}_{4}$.

\section{Zircon}

It is an adequate host of many rare metals such as $\mathrm{U}, \mathrm{Th}$, REE, Hf. It is one of the most important accessory mineral in granites. Its alteration 
during alkali metasomatism of granites induces serious redistribution of these metals (El-Kammar and El Mahdi, 2002). The crystal chemistry of zircon during metasomatism indicate that zircon vanishes or entirely disappears upon metasomatism (Recio et al., 1997).

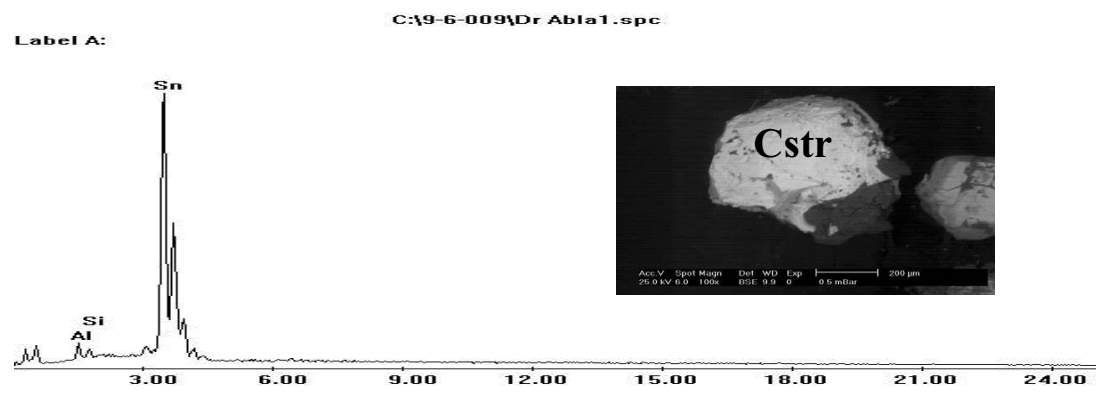

(A)

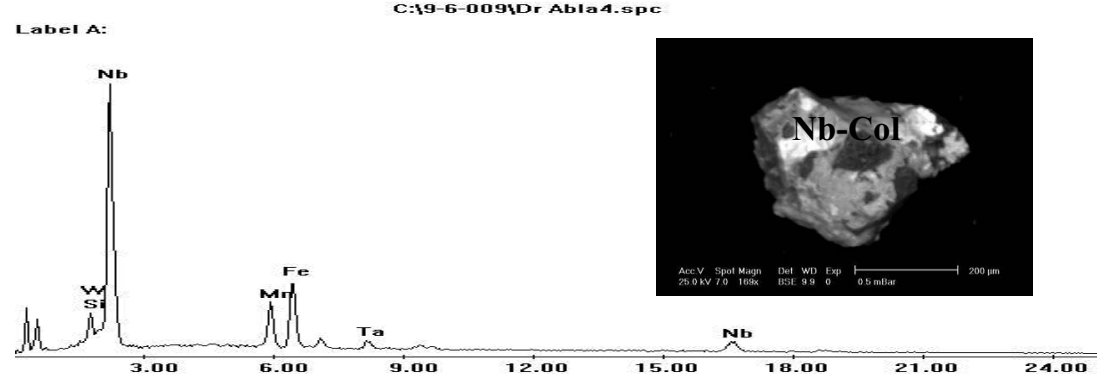

(B)

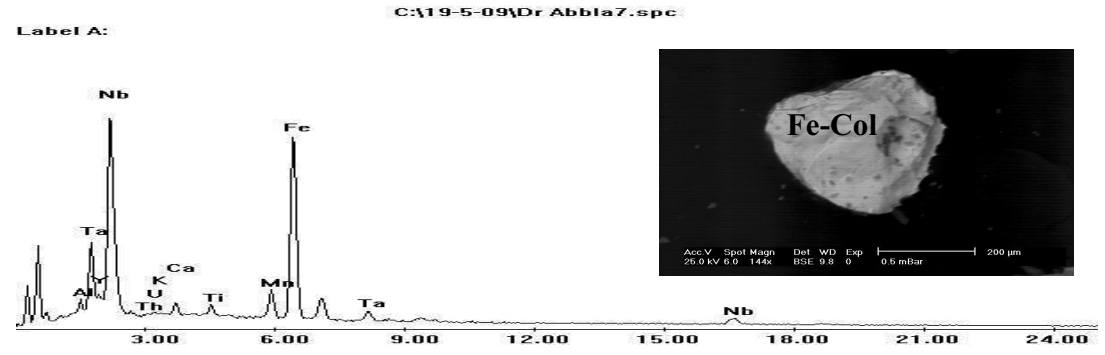

(C)

Fig. 5. BSE images and ESEM spectrum from pegmatite.
A) Cassiterite (Cstr).
B) Ferocolumbite (Nb-Col).
C) Nb-rich columbite (Fe-Col). 
Two types of zircon are encountered in the pegmatite of $\mathrm{Abu}$ Rusheid, namely; unaltered and altered zircons (Fig. 6B-C). In spite of the fact that zircons are good accommodator of the HREE, these elements have not been detected in any of the analyzed zircon possibly due to their mobilization during alteration. Alkali elements such as $\mathrm{Na}$ and $\mathrm{Ca}$ are common minor elements of all secondary zircon. The EDX analysis indicates marked enrichment of $\mathrm{Zr}$ over its heavy isovalent $\mathrm{Hf}$, where the $\mathrm{Zr} / \mathrm{Hf}$ ratio is averaging 12 which is far below the chondritic value (35). Wang et al. (2000) reported that the Hf enrichment in zircon, and the association of exotic REE and HFSE bearing minerals are linked to hydrothermal activity, suggesting that during the last stage of crystallization of the A-type magma, fluids enriched in REE, HFSE, F, $\mathrm{CO}^{2-}$ and $\mathrm{PO}_{4}^{3-}$ were released. The majority of scanned spot are composed of zircon with $\mathrm{ThO}_{2} / \mathrm{UO}_{2}$ ratio between $<0.5$ and 5 , due to the relative enrichment of Th over $\mathrm{U}$.

The color of the studied zircon varies between colorless and honey brown but sometimes stained with iron oxy-hydroxides. The EDX analysis refers to the increase of uranium with increasing $\mathrm{Fe}_{2} \mathrm{O}_{3}$ content possibly due to absorption.

\section{Allanite}

It occurs in pegmatite as irregular grains and crystals in reddish feldspars associated with zircon. It is brown, pitch-black but occasionally yellow in color (Fig. 3b). According to Simmons et al. (2003) the (Y, La or Ce) allanite is common in some NYF-type pegmatite and formed from a volatite-enriched magma.

\section{Monazite}

It is brown to reddish brown in color, and usually forms early in the crystallization sequence of pegmatite but may persist until the core margin/pocket zones of some pegmatite (Simmons et al., 2003). Cemonazite is predominant in the studied pegmatite. It occurs in association with xenotime, columbite and zircon. 


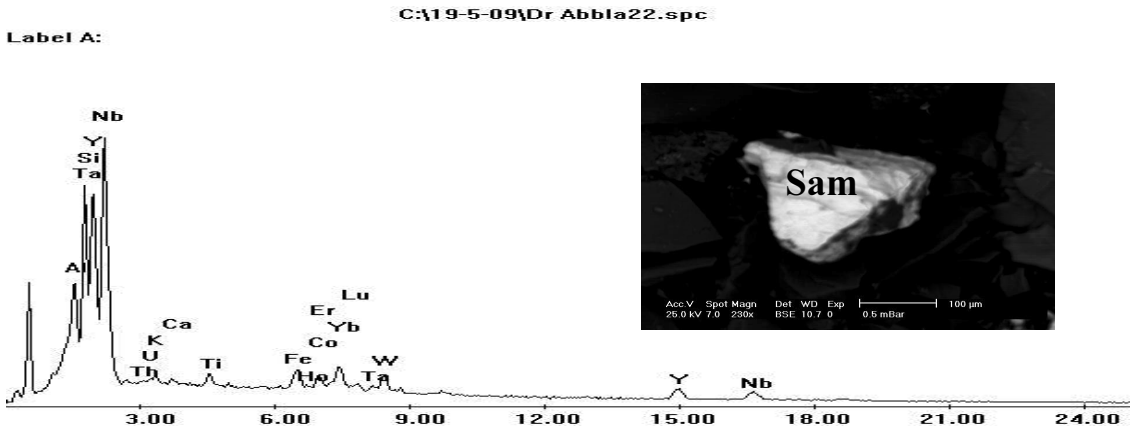

(A)

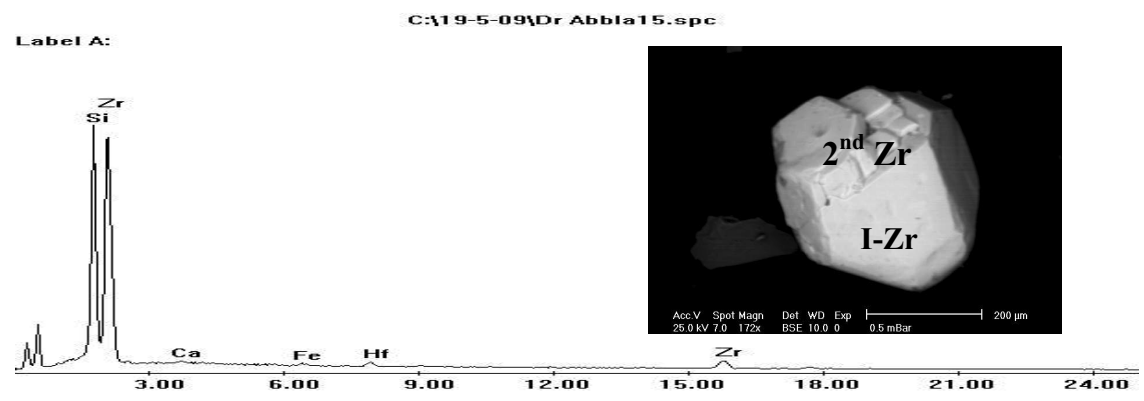

(B)

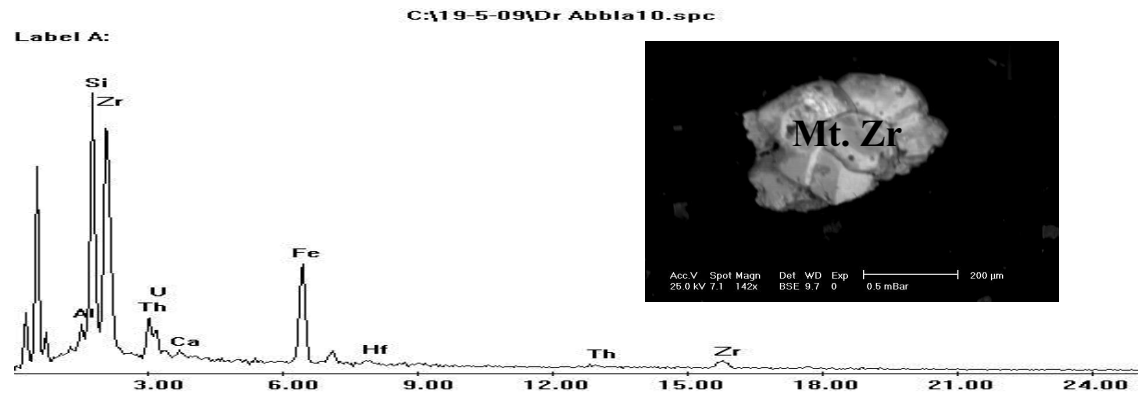

(C)

Fig. 6. BSE images and ESEM spectrum from pegmatite.
A. Samarskite.(Sam).
B. Two generation of zircon.(I-Zr \& $\left.2^{\text {nd }} \mathrm{Zr}\right)$.
C. Metamict zircon (Mtz).

\section{Xenotime}

It is uraniferous, brownish in color, occasionally pleochroic from pale pink to pale yellow. It is characterized by short to long prismatic 
bipyramid crystal shape (Fig. 3a). It is an accessory mineral in granites that occurs in both NYF- and LCT-type pegmatites. Like monazite, xenotime is much more prevalent in NYF-type pegmatite (Simmons et al., 2003). Xenotime is associated with fluorite and hematite. Parnell (1989), showed that xenotime exhibits significant substitution between U, Ca and Si. Kostov (1977) explained the substitution of tetravalent uranium $\left(\mathrm{U}^{+4}\right)$ by $\mathrm{Y}^{+3}$ in the crystal structures due to their similar atomic radii.

\section{Micas}

Both zimmwaldite $\left[\mathrm{K} \mathrm{Li}(\mathrm{Fe} \mathrm{Al})(\mathrm{Al}, \mathrm{Si})_{4} \mathrm{O}_{16}(\mathrm{OH}, \mathrm{F})_{2}\right]$, and phlogopite $\left[\mathrm{K} \mathrm{Mg} \mathrm{Al}\left(\mathrm{SiO}_{4}\right)_{3}\right]$ varieties of mica have been identified. However, a considerable quotient of these micas is altered into chlorite. The EDX analysis shows phologpite with smaller amount of $\mathrm{TiO}_{2}$ as a result of its alteration (Fig. 7a). It displays drab shades of brown color and nearly opaque. Zinnwaldite is a late hydrothermal products but it has been shown that some Li mica may be primary crystallized from the melt (Henderson et al., 1989). It ranges in color from brown, silvery gray or greenish.

Micas are associated with fluorite crystals varying from colourless to blue or even deep violet. The studied fluorite is of secondary origin from hydrothermal solution percolating in the pegmatite. It is generally a rare accessory phase in LCT-type magma but much more abundant in the NYF-type and alkalic pegmatite (Simmons et al., 2003).

\section{Pyrite}

It is associated with thorite, fluorite and silver. The EDX analysis shows its empirical composition (Fig.7b). Other opaques are represented by magnetite, hematite, goethite (Fig. 7c,d). The latter exhibits colloform texture (Fig. 7d) and sometimes replaces pyrite, magnetite and hematite.

\section{Silver Mineralization}

The geochemical results indicate that the highest silver values ( 872 $-1704 \mathrm{ppm}$ ) is due to native silver association. They are encountered in the studied pegmatite associating primary sulphide mineral (pyrite). The silver in the pegmatite is related to hydrothermal origin. 


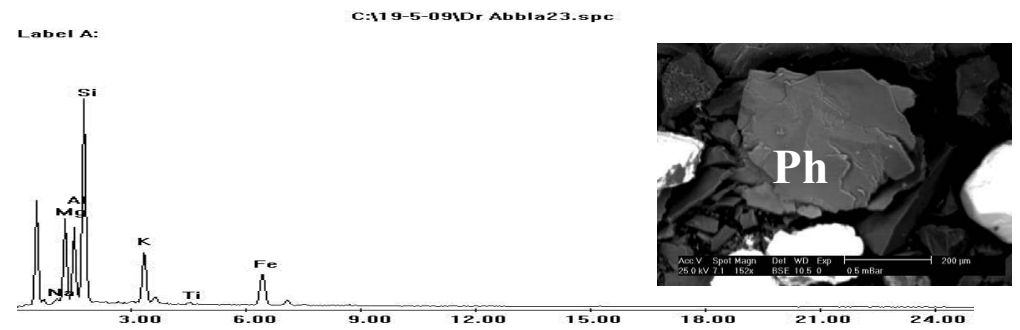

( a )

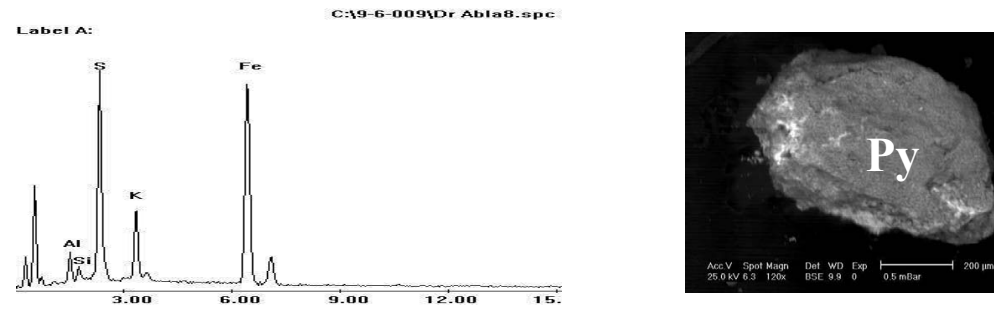

( b )

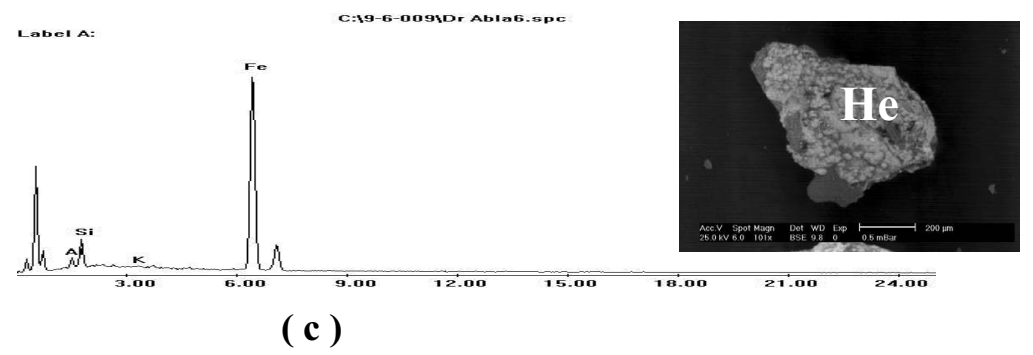

Label A:

C:119-5-097Dr Abblazespe
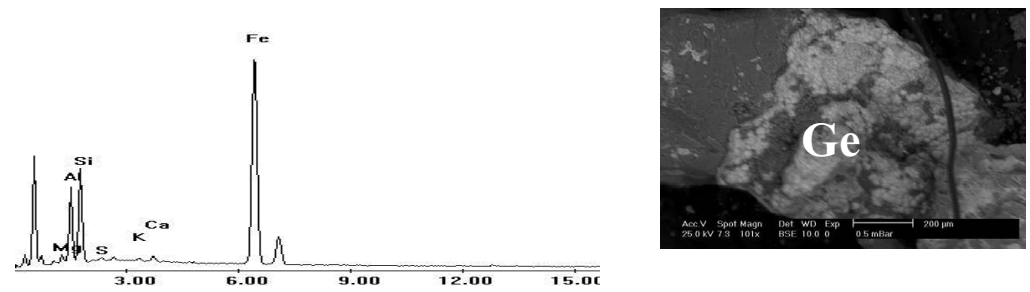

(d)

Fig. 7. BSE images and ESEM spectrum from pegmatite.

a) Phlogopite (Ph).

b) Pyrite (Py) .

c) Hematite (He) .

d) Colloform geothite (Ge). 
However, some authors tried to correlate between the presence of some minerals in the pegmatite, in one hand, and the depth of their magma crystallization on the other hand. Adam et al. (1980) stated that pegmatite emplaced at greater depth $(6-7 \mathrm{~km})$ are more likely to contain muscovite; those at moderate depth $(4-6 \mathrm{~km})$ may contain cassiterite, columbite-tantalite, beryl, petalite and others lithium minerals, and in those at shallow depths $(2-4 \mathrm{~km})$, calcite and fluorite are expectable. Since the studied pegmatite contains fluorite, columbite-tantalite, cassiterite, and lithium minerals, it may be emplaced at moderate to shallow depths.

In agreement with Collins (1996) the studied pegmatite that contains fluorite associated with the rare earth minerals, e.g., allanite, monazite and xenotime is formed in two stages. The first confirms a classic magmatic scheme; the second is post-magmatic and indicates multiphases of metasomatism. In the post magmatic stage, two phases of albitization and three phases of fluoritizations, silicification and dissolution have been traced (Voloshin, 1989). In the studied pegmatite, albitization, fluoritization and silicification have been recorded. In conclusion, the studied mineralized pegmatite is of NYF-type pegmatite.

\section{Geochemistry}

The studied pegmatites are diagnostically characterized by their high $\mathrm{SiO}_{2}(>72 \%)$, alkalis and $\mathrm{FeO} / \mathrm{MgO}$ ratio (9-18). They have low abundance of $\mathrm{FeO}(<0.81 \%), \mathrm{MgO}(<0.08 \%), \mathrm{CaO}(<0.88 \%) \mathrm{MnO}$ $(<0.07 \%)$ and $\mathrm{TiO}_{2}(<0.07 \%)$. The $\mathrm{Al}_{2} \mathrm{O}_{3}$ content ranges from $3 \%$ to $15 \%$ with $\mathrm{K} / \mathrm{Rb}$ below 2.3. Regarding the trace elements, they are characterized by their high Li (5-248 ppm), Rb (94-758ppm), Nb (78-805 ppm), Ta (10-190 ppm), Y(52-307 ppm), Th (37-699 ppm), U (31-262 $\mathrm{ppm})$ and $\mathrm{Pb}(56-207 \mathrm{ppm})$. In general, the concentration increases from the core to the wall zone. The studied pegmatites are depleted in Cs, $\mathrm{Sc}, \mathrm{Be}, \mathrm{W}, \mathrm{Sn}, \mathrm{Bi}, \mathrm{Mo}, \mathrm{Cu}, \mathrm{As}, \mathrm{W}, \mathrm{Co}$ and $\mathrm{Ni}$.

The variation in most elements (e.g., $\mathrm{Li}, \mathrm{Be}, \mathrm{Na}, \mathrm{Nb}, \mathrm{Ta}, \mathrm{U}$ and $\mathrm{Pb}$ ) can be attributed to the alteration processes especially the Nametasomatism that caused albitization of the studied pegmatites. 
Table 1. Results of major oxides (wt \%) of Pegmatite of Abu Rusheid area, South Eastern Desert, Egypt.

\begin{tabular}{ccccccccccc}
\hline Sample & $1 \mathrm{P}$ & $2 \mathrm{P}$ & $3 \mathrm{P}$ & $4 \mathrm{P}$ & $5 \mathrm{P}$ & $6 \mathrm{P}$ & $7 \mathrm{P}$ & $8 \mathrm{P}$ & $9 \mathrm{P}$ & $10 \mathrm{P}$ \\
\hline $\mathrm{SiO}_{2}$ & 71.57 & 77.74 & 93.24 & 91.32 & $\mathbf{8 2 . 1 2}$ & 76.10 & 93.79 & $\mathbf{8 2 . 4 1}$ & 71.98 & 91.85 \\
$\mathrm{TiO}_{2}$ & 0.01 & 0.02 & 0.00 & 0.00 & 0.01 & 0.07 & 0.00 & 0.01 & 0.01 & 0.01 \\
$\mathrm{Al}_{2} \mathrm{O}_{3}$ & 14.15 & 10.76 & 3.15 & 4.25 & 9.00 & 12.24 & 3.00 & 9.01 & 14.05 & 4.00 \\
$\mathrm{FeO}$ & 0.71 & 0.66 & 0.42 & 0.81 & 0.60 & 0.72 & 0.33 & 0.59 & 0.73 & 0.81 \\
$\mathrm{MnO}$ & 0.07 & 0.01 & 0.03 & 0.04 & 0.00 & 0.02 & 0.01 & 0.01 & 0.07 & 0.05 \\
$\mathrm{MgO}$ & 0.08 & 0.03 & 0.01 & 0.01 & 0.04 & 0.66 & 0.01 & 0.05 & 0.08 & 0.01 \\
$\mathrm{CaO}$ & 0.88 & 0.14 & 0.12 & 0.03 & 0.23 & 1.45 & 0.03 & 0.25 & 0.86 & 0.03 \\
$\mathrm{Na}_{2} \mathrm{O}$ & 7.64 & 6.83 & 0.48 & 0.83 & 4.68 & 8.17 & 0.47 & 4.62 & 7.48 & 0.77 \\
$\mathrm{~K}_{2} \mathrm{O}$ & 4.88 & 3.77 & 2.52 & 2.65 & 3.11 & 0.53 & 2.32 & 3.04 & 4.60 & 2.44 \\
$\mathrm{P}_{2} \mathrm{O}_{5}$ & 0.01 & 0.00 & 0.00 & 0.00 & 0.00 & 0.01 & 0.01 & 0.00 & 0.01 & 0.00 \\
LOI & 0.23 & 0.17 & 0.21 & 0.15 & 0.19 & 0.22 & 0.21 & 0.18 & 0.17 & 0.2 \\
total & 100.23 & 100.17 & 100.21 & 100.15 & 100.19 & 100.22 & 100.21 & 100.18 & 100.17 & 100.2 \\
\hline
\end{tabular}

* S.No: P3,P4,P7, \& P10 Pegmatite core samples

* S.No: P1,P2,P5,P6 \&P9 Pegmatite wall samples

Table 2. Results of trace elements (ppm) of Pegmatite of Abu Rusheid area, South Eastern Desert, Egypt.

\begin{tabular}{ccccccccccc}
\hline S.No. & $1 P$ & $2 P$ & $3 P$ & $4 P$ & $5 P$ & $6 P$ & $7 P$ & $8 P$ & $9 P$ & $10 P$ \\
\hline Li & 5.40 & 9.10 & 222.10 & 248.00 & 30.30 & 83.50 & 107.70 & 28.40 & 6.60 & 243.00 \\
Be & 3.00 & 1.00 & uld & uld & 2.00 & 18.00 & uld & 2.00 & 3.00 & uld \\
Sc & 0.80 & 0.80 & uld & 0.20 & 0.80 & 1.90 & 0.10 & 0.90 & 0.90 & 0.40 \\
V & 3.00 & 2.00 & 2.00 & 2.00 & 2.00 & 8.00 & 2.00 & uld & 3.00 & 2.00 \\
Cr & 16.00 & 47.00 & 93.00 & 91.00 & 61.00 & 49.00 & 82.00 & 60.00 & 17.00 & 92.00 \\
Mn & 519.00 & 109.00 & 219.00 & 336.00 & 63.00 & 167.00 & 114.00 & 64.00 & 524.00 & 352.00 \\
Co & 1.20 & 0.40 & 0.60 & 0.80 & 0.50 & 3.10 & 0.50 & 0.60 & 1.10 & 0.70 \\
Ni & 1.60 & 1.60 & 2.50 & 2.20 & 2.40 & 22.10 & 1.80 & 2.30 & 2.10 & 2.60 \\
Cu & 7.33 & 13.73 & 4.97 & 9.04 & 6.30 & 6.33 & 2.78 & 5.87 & 7.84 & 9.24 \\
Zn & 748.80 & 44.90 & 54.70 & 226.50 & 77.30 & 222.90 & 49.50 & 74.70 & 779.60 & 227.40 \\
Ga & 72.87 & 61.41 & 14.34 & 17.37 & 29.51 & 36.81 & 13.69 & 28.49 & 72.33 & 17.15 \\
As & 3.90 & 0.90 & 1.70 & 0.50 & 2.20 & 5.00 & 1.10 & 2.60 & 4.60 & 1.30 \\
Rb & 738.90 & 443.80 & 447.60 & 490.20 & 112.80 & 93.70 & 414.70 & 111.50 & 758.40 & 474.90 \\
Sr & 36.00 & 34.00 & 27.00 & 12.00 & 79.00 & 134.00 & 70.0 & 77.00 & 36.00 & 11.00 \\
Y & 79.80 & 63.40 & 306.50 & 53.30 & 66.60 & 181.10 & 21.50 & 51.80 & 86.60 & 52.30 \\
\hline
\end{tabular}


Table 2. cont.

\begin{tabular}{|c|c|c|c|c|c|c|c|c|c|c|}
\hline S.No. & $1 P$ & $2 P$ & $3 P$ & $4 P$ & $5 P$ & $6 P$ & $7 P$ & $8 P$ & $9 P$ & $10 P$ \\
\hline $\mathrm{Zr}$ & $\mathbf{5 5 0 . 0 0}$ & 361.70 & 21.60 & 66.90 & 90.80 & 68.70 & 30.80 & 76.40 & $\mathbf{5 8 3 . 5 0}$ & 82.70 \\
\hline Nb & 805.30 & 783.41 & 120.96 & 125.15 & 300.88 & 427.25 & 78.47 & 322.77 & 767.00 & 101.69 \\
\hline Mo & 2.27 & 1.36 & 3.95 & 2.68 & 1.60 & 2.05 & 3.69 & 1.56 & 2.16 & 2.51 \\
\hline Ag & Uld & uld & 1704.00 & uld & Uld & uld & 872.00 & Uld & uld & uld \\
\hline Cd & 1.11 & 0.32 & 0.05 & 0.32 & 0.26 & 0.22 & 0.05 & 0.27 & 1.18 & 0.33 \\
\hline Sn & 11.40 & 10.10 & 5.20 & 10.00 & 2.60 & 14.20 & 2.50 & 2.30 & 11.60 & 10.10 \\
\hline Cs & 2.90 & 1.30 & 1.10 & 2.50 & 0.80 & 1.90 & 1.00 & 0.70 & 3.00 & 2.30 \\
\hline Ba & 266.00 & 106.00 & 23.00 & 32.00 & 296.00 & 84.00 & 23.00 & 290.00 & 272.00 & 31.00 \\
\hline Hf & 27.52 & 21.99 & 1.16 & 3.91 & 5.64 & 6.59 & 1.65 & 4.46 & 28.75 & 4.52 \\
\hline Ta & 71.20 & 69.50 & 10.10 & 13.00 & 26.40 & 189.50 & 6.40 & 30.80 & 65.50 & 10.80 \\
\hline $\mathbf{W}$ & 6.80 & 10.10 & 5.20 & 5.30 & 6.40 & 6.80 & 6.10 & 6.70 & 5.60 & 4.10 \\
\hline Au & Uld & Uld & Uld & Uld & Uld & Uld & uld & Uld & $<0.1$ & $<0.1$ \\
\hline $\mathbf{P b}$ & 56.00 & 102.96 & 122.48 & 123.42 & 61.29 & 207.99 & 84.79 & 61.49 & 58.66 & 117.00 \\
\hline $\mathbf{B i}$ & 0.61 & 18.35 & 14.87 & 0.89 & 3.94 & 0.31 & 0.85 & 4.12 & 0.60 & 0.68 \\
\hline $\mathbf{U}$ & 133.60 & 41.30 & 16.60 & 30.70 & 36.30 & 262.30 & 18.20 & 30.60 & 138.50 & 30.70 \\
\hline Th & 117.30 & 86.70 & 37.30 & 49.90 & 84.40 & 699.50 & 29.90 & 81.50 & 121.60 & 45.70 \\
\hline
\end{tabular}

Detection Limit for $\mathrm{Be}=1, \mathrm{Sc}=1, \mathrm{~V}=0.1, \mathrm{Ag}=20$ and $\mathrm{Au}=0.1 \mathrm{ppm}$.

Friedch, et al. (1987) stated that uranium is enriched during albitization which is a process of a base exchange between interacting high temperature, alkaline fluids and the early formed feldspar within a nearly consolidation granite. This enrichment in rare elements nominates the studied pegmatite as NYF type according to Cerny (1991b).

In the ternary diagram (Fig. 8a) of Shand 1951; these pegmatites are peraluminous The pegmatites are subalkaline, as can be seen in the diagram of alkalis versus silica (Fig. 8b). On the AFM ternary diagram (Fig. 8c), the samples are plotted near the $\left(\mathrm{Na}_{2} \mathrm{O}+\mathrm{K}_{2} \mathrm{O}\right)$ sideline reflecting calc- alkaline affinity. The pegmatites show high $\mathrm{Rb}$ and low Sr contents under the control of the fractional crystallization (Fig. 8d). Sr is concentrated by plagioclases in early stages, whereas $\mathrm{Rb}$ remains in the melt and increases progressively with crystallization. 
Table 3. Results of REE (ppm) of pegmatite of Abu Rusheid area, south eastern desert, Egypt.

\begin{tabular}{|c|c|c|c|c|c|c|c|c|c|c|}
\hline S. NO. & 1P & $2 P$ & $3 P^{*}$ & $4 P^{*}$ & $5 P$ & $6 P$ & $7 P^{*}$ & $8 P$ & 9P & $10 \mathrm{P}^{*}$ \\
\hline $\mathbf{L a}$ & 5.70 & 3.10 & 14.20 & 2.70 & 1.80 & 26.70 & 1.10 & 1.60 & 6.10 & 2.50 \\
\hline $\mathrm{Ce}$ & 20.48 & 14.76 & 113.32 & 27.86 & 8.75 & 67.91 & 4.93 & 7.61 & 20.98 & 25.08 \\
\hline Pr & 3.30 & 1.70 & 8.70 & 2.40 & 1.30 & 9.40 & 0.60 & 1.10 & 3.50 & 2.20 \\
\hline Nd & 8.80 & 5.00 & 23.00 & 6.30 & 5.40 & 29.30 & 1.80 & 3.70 & 8.90 & 6.20 \\
\hline Sm & 3.10 & 2.20 & 9.30 & 2.80 & 2.70 & 10.10 & 0.80 & 1.90 & 3.20 & 2.70 \\
\hline Eu & 0.10 & 0.10 & 0.10 & 0.10 & 0.10 & 0.80 & 0.10 & 0.10 & 0.10 & 0.10 \\
\hline Gd & 3.20 & 2.90 & 11.50 & 2.80 & 2.90 & 12.10 & 0.80 & 2.00 & 3.30 & 2.70 \\
\hline Tb & 1.50 & 1.30 & 4.90 & 1.30 & 1.20 & 4.10 & 0.40 & 1.00 & 1.70 & 1.20 \\
\hline Dy & 17.80 & 13.50 & 53.10 & 12.70 & 12.90 & 41.70 & 4.40 & 10.10 & 19.10 & 13.20 \\
\hline Ho & 5.10 & 3.60 & 13.40 & 3.30 & 3.40 & 9.70 & 1.20 & 2.70 & 5.70 & 3.20 \\
\hline Er & 23.20 & 15.80 & 61.40 & 14.20 & 14.60 & 42.70 & 5.20 & 11.10 & 23.90 & 13.80 \\
\hline $\mathbf{T m}$ & 4.90 & 3.50 & 12.40 & 2.90 & 3.10 & 10.00 & 1.10 & 2.40 & 5.00 & 2.80 \\
\hline $\mathbf{Y b}$ & 41.70 & 31.40 & 111.10 & 26.30 & 28.50 & 101.60 & 9.70 & 21.50 & 44.80 & 24.40 \\
\hline Lu & 6.20 & 4.90 & 16.50 & 3.60 & 4.10 & 15.00 & 1.40 & 3.10 & 6.40 & 3.50 \\
\hline$\sum \mathrm{REE}$ & 145.08 & 103.76 & 452.92 & 109.26 & 90.75 & 381.11 & 33.53 & 69.91 & 152.68 & 103.58 \\
\hline $\mathrm{Ce} / \mathrm{Ce}^{*}$ & 1.10 & 1.51 & 1.30 & 1.02 & 1.31 & 1.06 & 2.37 & 2.40 & 1.42 & 2.35 \\
\hline $\mathbf{E u} / \mathbf{E} \mathbf{u}^{*}$ & 0.10 & 0.13 & 0.12 & 0.24 & 0.17 & 0.10 & 0.03 & 0.12 & 0.40 & 0.12 \\
\hline $\mathbf{L} / \mathbf{H}$ & 0.12 & 0.10 & 0.09 & 0.19 & 0.09 & 0.12 & 0.15 & 0.17 & 0.12 & 0.16 \\
\hline t1 & 1.48 & 1.54 & 1.42 & 1.31 & 1.58 & 1.53 & 1.74 & 1.84 & 1.59 & 1.98 \\
\hline t3 & 1.51 & 1.57 & 1.44 & 1.32 & 1.68 & 1.64 & 1.87 & 1.97 & 1.72 & 2.66 \\
\hline $\mathbf{T} 1,3$ & 1.44 & 1.49 & 1.40 & 1.30 & 1.49 & 1.43 & 1.62 & 1.70 & 1.47 & 1.47 \\
\hline Feo/Mgo & 8.90 & 25.30 & 42.00 & 81.00 & 12.00 & 1.09 & 33.00 & 11.00 & 9.00 & 81.00 \\
\hline $\mathrm{K}_{2} \mathrm{O} / \mathrm{Na}_{2} \mathrm{O}$ & 0.60 & 0.55 & 5.00 & 3.00 & 0.67 & 0.06 & 4.90 & 0.65 & 0.60 & 3.14 \\
\hline $\mathbf{R b} / \mathbf{S r}$ & 20.50 & 13.05 & 16.57 & 40.85 & 1.42 & .70 & 59.24 & 1.44 & 21.06 & 43.17 \\
\hline $\mathbf{K} / \mathbf{R b}$ & 0.50 & 0.70 & 0.47 & 0.45 & 2.30 & 0.64 & 0.64 & 2.26 & 0.05 & 0.42 \\
\hline $\mathrm{Nb} / \mathrm{Ta}$ & 11.31 & 11.27 & 11.40 & 2.25 & 10.48 & 11.71 & 11.98 & 9.63 & 12.26 & 9.42 \\
\hline $\mathbf{Z r} / \mathbf{H f}$ & 19.99 & 16.45 & 16.10 & 10.42 & 17.13 & 20.30 & 18.62 & 17.11 & 18.67 & 18.30 \\
\hline Y/Ho & 15.65 & 17.61 & 19.59 & 18.67 & 19.19 & 15.19 & 22.87 & 16.15 & 17.92 & 16.34 \\
\hline $\mathbf{T h} / \mathbf{U}$ & 0.88 & 2.10 & 2.33 & 2.67 & 2.66 & 0.88 & 2.25 & 1.63 & 1.64 & 1.49 \\
\hline
\end{tabular}

$\mathrm{T} 1, \mathrm{~T} 3, \mathrm{~T} 1.3$ mean the quantitative measures of the $1^{\text {st }}$ tetrad, $3^{\text {rd }}$ tetrad and total tetrad of $1^{\text {st }}+3^{\text {rd }}$ tetrad respectively. 
A

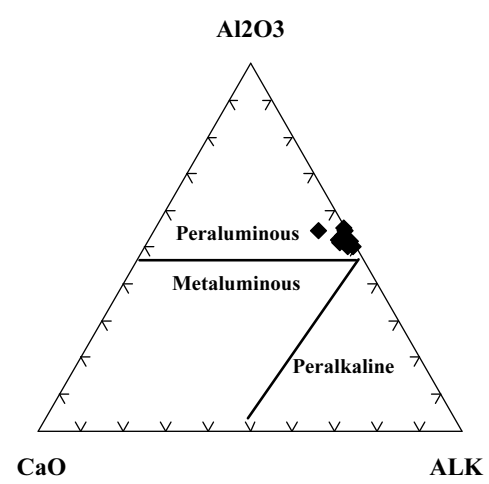

$\mathrm{C}$

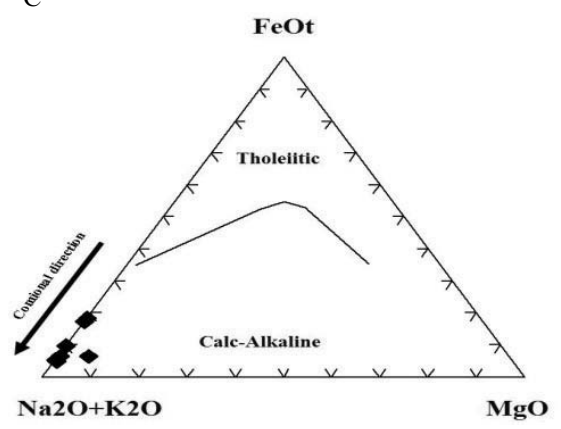

B

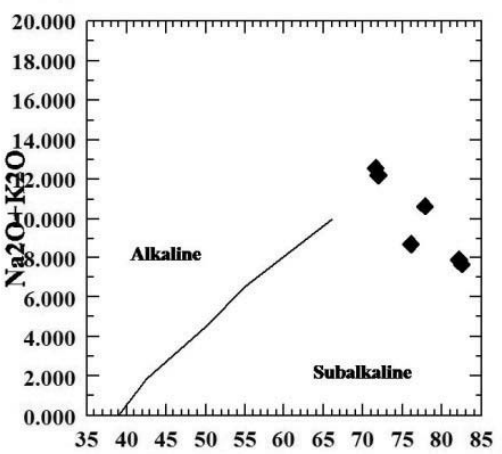

SiO2

$\mathrm{D}$

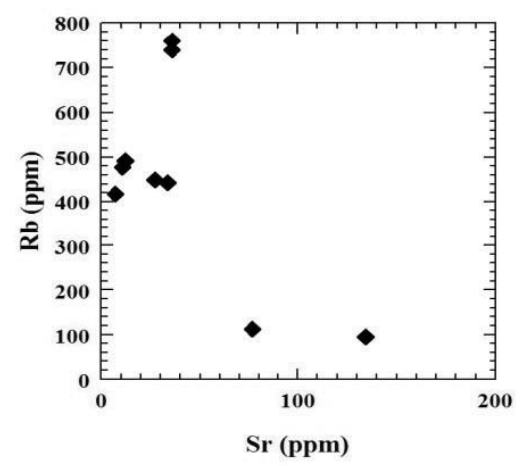

Fig. 8. (A) $\mathrm{Al}_{2} \mathrm{O}_{3}-\mathrm{CaO}-\left(\mathrm{Na}_{2} \mathrm{O}+\mathrm{K}_{2} \mathrm{O}\right)$ diagram after Shand, (1951). (B) Alkalies vs. silica diagram (Irvin and Baragar, 1971). (C) AFM diagram (Irvine and Baragar, 1971) Tensional trend after Petro et al. (1979). (D) Sr vs. Rb diagram.

The pegmatites are fairly similar to the continental crust (Taylor and Mcl-emmen, 1985) with respect to $\mathrm{Ba}, \mathrm{Sr}, \mathrm{V}, \mathrm{Ni}, \mathrm{Cu}$ and $\mathrm{Zn}$ (Fig. 9), This suggests either derivation from crustal materials with nearly the same composition and/or that crustal contamination has played the major role in the generation of these pegmatite. The $\mathrm{Rb} / \mathrm{Sr}$ ratio is an important criterion to distinguish between magma coming from the upper crust $(\mathrm{Rb} / \mathrm{Sr}=0.25)$ and lower crust $(\mathrm{Rb} / \mathrm{Sr}=0.02-0.04)$ (Schroll, 1976). The studied pegmatites have $\mathrm{Rb} / \mathrm{Sr}$ ratio vary from 0.7 to 59.24 suggesting crustal contamination during the rise of the magma.

\section{Geochemistry of the Isovalents}

Some of the elements pairs (e.g., Zr-Hf, Nb-Ta, Y-Ho and Th-U) that exhibit chemical coherence in other geological environments may be 
strongly fractionated by pegmatite-forming processes. The mutual abundance and distribution of these isovalents, in most geological environments, follow the popularly known Goldschmidt's rule (i.e, charge and radius control, CHARAC). Detailed studies have been published during the last three decades on the marked fractionation of such geological twins under variety of geological environments. Among these studies, Bau et al. (1995), and Bau (1996, 1999) should be mentioned. The fractionation takes places either through depletion or enrichment of the heaver isovalent relative to the lighter ones. The nondifferentiated ratios of the isovalent are; 35, 17, 28, 3 for $\mathrm{Zr} / \mathrm{Hf}, \mathrm{Nb} / \mathrm{Ta}$, $\mathrm{Y} / \mathrm{Ho}$ and $\mathrm{Th} / \mathrm{U}$, respectively (Weyer et al., 2002).

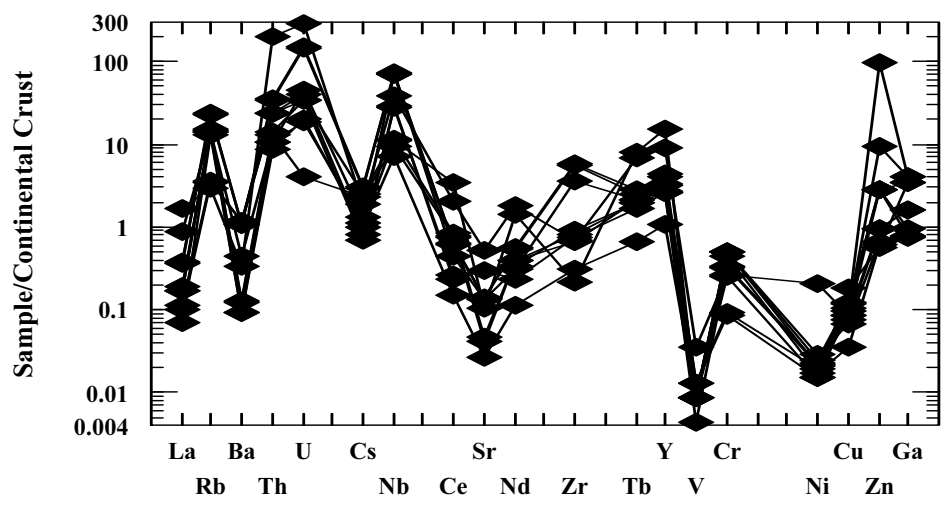

Fig. 9. Spider diagram of Abu Rusheid pegmatite (Taylor and Mclennan, 1985).

In the present study, the pegmatite displays strong fractionation of the isovalents. The $\mathrm{Zr} / \mathrm{Hf}$ ratio varies between 10 and 20, averaging 18, suggesting significant change in the crystal chemistry of zircon towards increasing contents of Hf. According to Bau (1996) and Takohashi et al. (2002) such fractionation may take place during alkali metasomatic alteration. Also, the $\mathrm{Nb} / \mathrm{Ta}$ fractionation is generally well developed in $\mathrm{Nb}$ and $\mathrm{Ta}$ oxide minerals from REL-L (rare element $\mathrm{Li}$ bearing) pegmatites (e.g. Cerny and Ercit, 1989, Linnen 1998) and also in some REE-enriched pegmatites (Ercit 2005). Nb/Ta ratio varies between 9 and 12 , averaging 10 (Table 3 ) which is below the chondritic ratio refer to the decisive increase in the $\mathrm{Ta}$ due to effect of hydrothermal solution. Magmatic rocks of continental crust origin generally have low $\mathrm{Nb} / \mathrm{Ta}$ ratio (11-12) (Wades and Wood, 2001). 
The $\mathrm{Y} / \mathrm{Ho}$ ratio ranges from 15 to 23 , averaging 18 which is below the chondritic ratio. Bau et al. (1995) suggest the complexation with fluorine as major cause for values $>28$, while the complexing with bicarbonate is assumed to generate values $<28$. The positive relation between $\mathrm{Y} / \mathrm{Ho}$ ratio and $\mathrm{Th} / \mathrm{U}$ ratio can be interpreted by the common effect of hydrothermal solution (El Mahdy, 2008), (Fig. 10a). The Th/U ratio (1.8) is below the chondritic ratio due to enrichement in thorium or removal of uranium (Table 3 ).
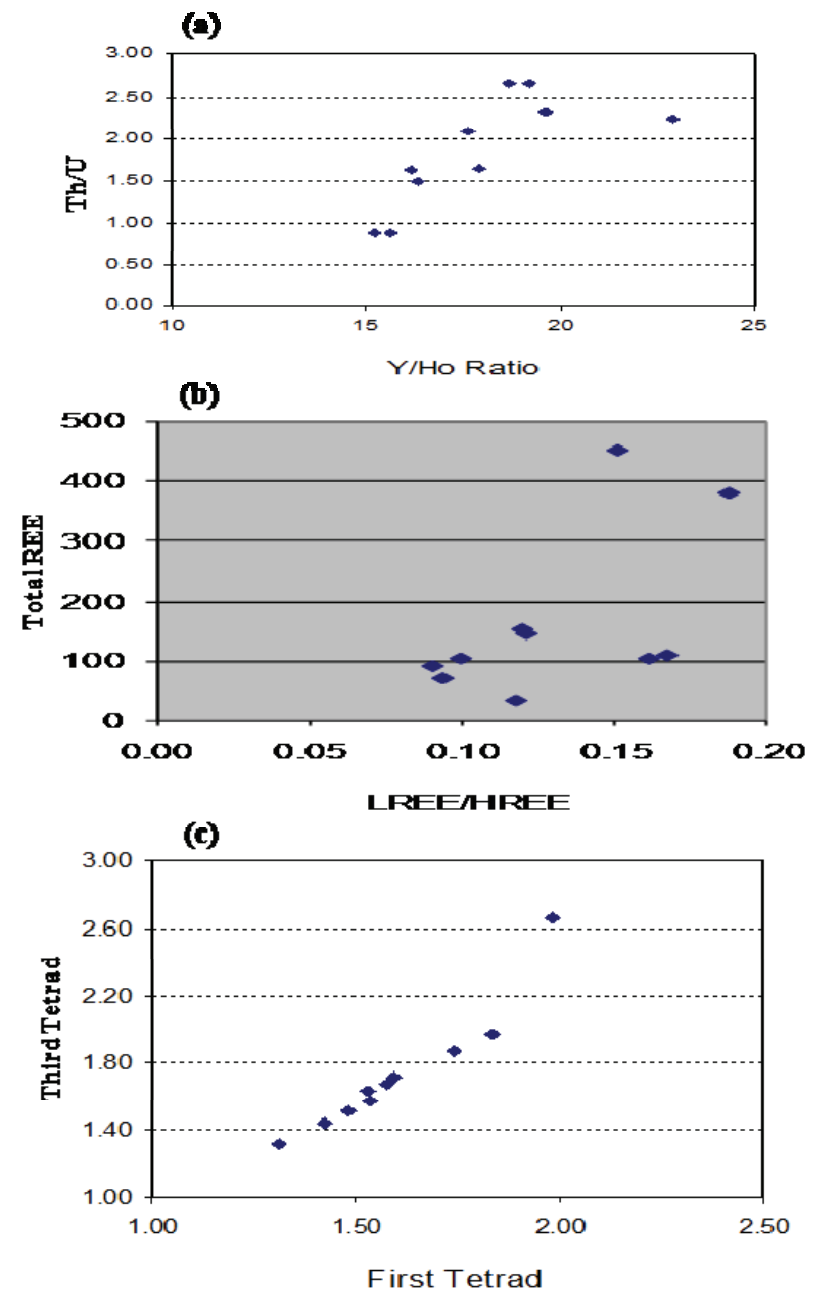

Fig. 10. (a) Positive relation between $\mathrm{Y}-\mathrm{Ho}$ ratio and $\mathrm{Th} / \mathrm{U}$ ratio. (b) Positive relation between LREE / HREE and total REE. (c) Positive relation between First Tetrad and Third Tetrad. 
From the above geochemical study of isovalents, it can be assumed influence of fluorine-rich hydrothermal solutions. The distinct behavior of the isovalent ratios $(\mathrm{Zr} / \mathrm{Hf}, \mathrm{Nb} / \mathrm{Ta}, \mathrm{Y} / \mathrm{Ho}$ and $\mathrm{Th} / \mathrm{U})$ during alterations seems to be non-chondritic and is no longer exclusive to the control of ionic radius and charge.

\section{REE Geochemistry}

The total REE content in the pegmatite ranges from 33.5 to 452.9 ppm with LREE/HREE ratio ranges from 0.09 to 0.12 (Table 3). Pegmatite has clear negative Eu anomalies, with $\mathrm{Eu} / \mathrm{Eu}^{*}=0.03-0.4$ (Fig. 12a). Also, the presence of positive Ce anomaly $\left(\mathrm{Ce} / \mathrm{Ce}^{*}\right)$ ranging from 1.06 to 2.37 is attributed to occurrence of Ce-monazite and to oxidizing conditions.

The positive relation between the total REE and the LREE/HREE ratio (Fig. 10b) indicates that REE budget is mainly imparted by the light ones. This can be attributed to the fluxing nature for both $\mathrm{Na}$ and fluorine-rich solutions which may weaken (metamictize) the structure of the HREEs hosting minerals like zircon and xenotime and promoting HREE re-concentration. The recent advances demonstrate that such alteration initiates tetrad effect that correlates with other geochemical, mineralogical and petrographical indicators (Irber 1999; Monecke et al., 2002; and Takahashi et al., 2002). The positive relation between the first tetrad and third is clear as see in Fig. 10c.

The calculated tetrad effect in the pegmatite of Abu-Rusheid demonstrates clear tendency towards the ratios of the common isovalents such as $\mathrm{Zr} / \mathrm{Hf}, \mathrm{Nb} / \mathrm{Ta}$ and $\mathrm{Y} / \mathrm{Ho}$ (Fig. 11). However, the tetrad effect seems not to be mutual with the content of $\mathrm{Na}_{2} \mathrm{O}$ and $\mathrm{Rb} / \mathrm{Sr}$ (Fig. 11). The absence of coherence between tetrad effect and soda content may indicate insignificant role of the Na-metasomatism in developing the tetrad effect.

Irber, 1999 proposed quantification method which depends on determination of the deviation of a REE pattern with tetrad effect from hypothetical tetrad effect-free REE pattern. 

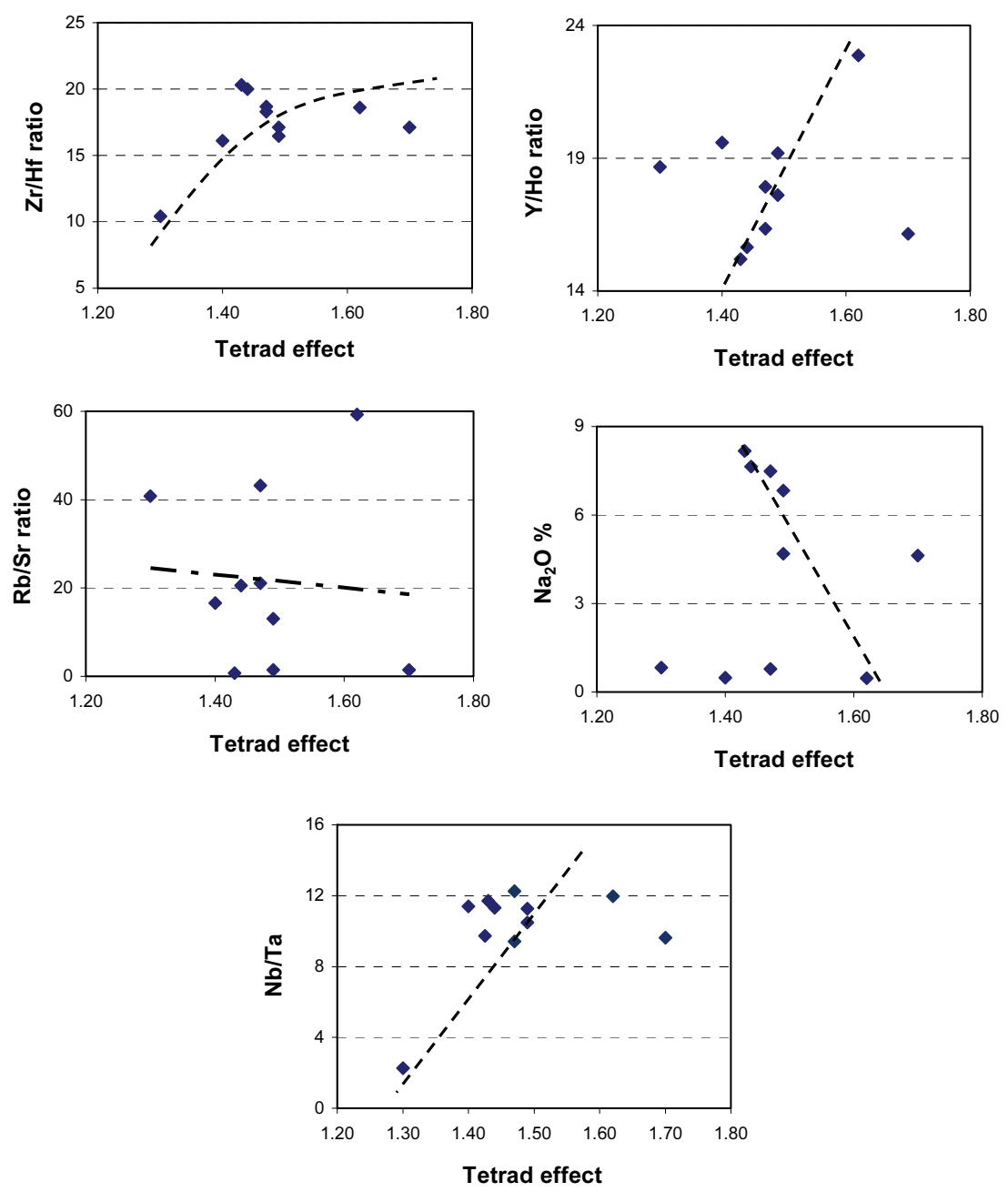

Fig. 11. Variation in $\mathrm{Zr} / \mathrm{Hf}, \mathrm{Y} / \mathrm{Ho}, \mathrm{Rb} / \mathrm{Sr}, \mathrm{Na}_{2} \mathrm{O}$ and $\mathrm{Nb} / \mathrm{Ta}$ versus $\mathrm{T}_{1,3}$ in pegmatite of $\mathrm{Abu}-$ Rusheid.

To determine the hypothetical tetrad effect-free REE pattern, the corner points of the single tetrads La-Nd serve as a respective reference. A virtual line is drawn in between these corner points, and the mean deviation of $\mathrm{Ce}$ and $\mathrm{Pr}$ (and $\mathrm{Tb}$, Dy) from this line expresses the contribution of the respective tetrad (Eqns. 1 and 2). The geometric mean of both values for the first $\left(t_{1}\right)$ and the third tetrad $\left(t_{3}\right)$ yields the overall value of the tetrad effect (Eqn. 3: $\mathrm{TE}_{1.3}$ ).

$$
\mathrm{t}_{1}=\left(\mathrm{Ce} / \mathrm{Ce}{ }^{\prime} \mathrm{x} \operatorname{Pr} / \mathrm{Pr}^{\prime}\right)^{0.5}
$$


$\mathrm{t}_{3}=\left(\mathrm{Tb} / \mathrm{Tb} b^{\prime} \mathrm{x} \text { Dy / Dy' }\right)^{0.5}$

With $\mathrm{Ce} / \mathrm{Ce}=\mathrm{Ce}_{\mathrm{cn}} /\left(\mathrm{La}_{\mathrm{cn}}{ }^{2 / 3} \mathrm{x} \mathrm{Nd}_{\mathrm{cn}}{ }^{1 / 3}\right)$

$$
\begin{aligned}
& \left.\operatorname{Pr} / \operatorname{Pr}^{\prime}=\operatorname{Pr}_{\mathrm{cn}} / \mathrm{La}_{\mathrm{cn}}{ }^{1 / 3} \times \mathrm{Nd}_{\mathrm{cn}}{ }^{2 / 3}\right) \\
& \mathrm{Tb} / \mathrm{Tb}^{\prime}=\mathrm{Tb}_{\mathrm{cn}} /\left(\mathrm{Gd}_{\mathrm{cn}}{ }^{2 / 3} \times \mathrm{Ho}_{\mathrm{cn}}{ }^{1 / 3}\right) \\
& \mathrm{Dy} / \mathrm{Dy}{ }^{\prime}=\mathrm{Dy}_{\mathrm{cn}} /\left(\mathrm{Gd}_{\mathrm{cn}}{ }^{1 / 3} \times \mathrm{Ho}_{\mathrm{cn}}{ }^{2 / 3}\right)
\end{aligned}
$$

Degree of the tetrad effect $=\mathrm{TE}_{1.3}=(\mathrm{t} 1 \mathrm{xt} 3)^{0.5}$

The calculated values of the tetrad effect (Eqn. 3: $\mathrm{TE}_{1.3}$ ) range from 1.00 for a REE pattern without tetrad effect and only samples with values of $\mathrm{TE}_{1.3}>1.10$ are considered to show the tetrad effect, where at $\mathrm{TE}_{1.3}>$ 1.10 the tetrad effect become well visible. For individual tetrad (ti), the value of ti is larger than one for a convex tetrad, equal to one if the elements plot on a straight line, and smaller than one for a convex tetrad.

The chonderite-normalized REE patterns of the pegmatite show Mtype tetrad effect similar to that quoted by Masuda et al. (1987) (Fig. 12a). The intensity of the tetrad effect for the REE patterns of the pegmatite was calculated by using the methods of Irber (1999) because of the simplicity of the calculation and also of the convenience of the composition with the calculated data of Irber (1999), although Monecke et al. (2002) have proposed another method to quantify the degree of the tetrad effect. The calculated $\mathrm{TE}_{1,3}$ values for the REE patterns of the pegmatites are significantly larger than unity ranging from 1.44 to 1.7 (Table 3). The comparison between the REE patterns of core and wall zone of pegmatite show that the core is higher in Ce than the wall zone (Fig. 12b).

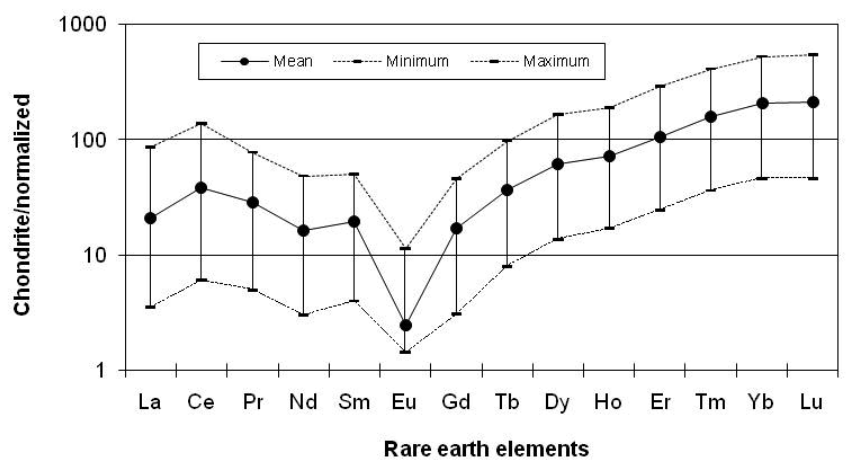

Fig. 12A. Chondrite - normalized REE pattern of pegmatite, chondrite values are taken from Anders and Grevesse (1989). 


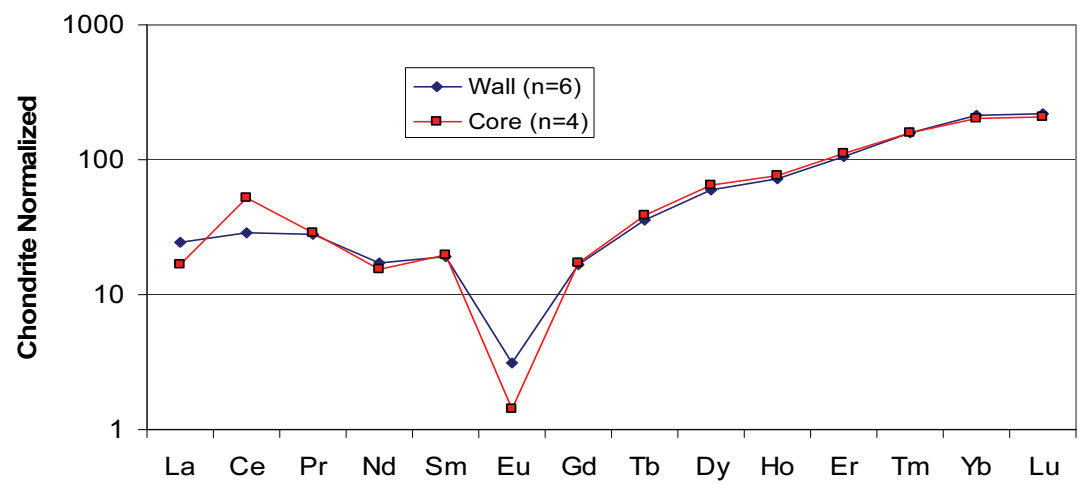

Fig. 12B. Chondrite-normalized REE pattern of core and wall zone of pegmatite, chondrite values are taken from Anders and Grevesse (1989).

\section{Radioactivity}

The early crystallization of uranothorite would lead to significant uranium-enrichment in residual fluids. On the other hand, early crystallization of zircon and or/apatite would lead to Th-enrichment in the residual fluids (Pagel, 1982). Also accessory minerals show high solubility with the peralkaline index (Montel, 1985). The high solubility of the accessory minerals in alkaline melt leads to the concentration of most trace elements $(\mathrm{Zr}$, Th \& P). The high concentration of these elements in the residual magma together with the classical elements $U$, $\mathrm{Nb}$ and Fe leads to the crystallization of complex and abundant accessory minerals from this highly differentiated sub-alkaline melt (Cuney and Friedich, 1987).

The origin of the secondary mineral (autunite) is mainly related to alteration of primary minerals by the action of oxidizing fluids and mobilization of uranium and then redeposition in other forms. Uraninite forms a complete solid solution with thorianite $\left(\mathrm{ThO}_{2}\right)$, and contains amount of metal and heavy metal impurities (Allen et al., 1982; and Naito et al. 1989). Cathelineaus and Holliger (1987), stated that the uranium mineralization is affected by the different stages of alteration, these stages of leaching, mobility and redeposition of $U$ are affected by hydrothermal solutions and supergene fluids causing oxidation of the medium. 
Uranium content of the pegmatite ranges from 18 to $262 \mathrm{ppm}$ while thorium from 30 to $699 \mathrm{ppm}$. Sminov (1984) suggested that the low $\mathrm{Th} / \mathrm{U}$ ratio (less than 3 ) in granite is due to the effect of fluids carrying uranium mineralization. The studied pegmatites have $\mathrm{Th} / \mathrm{U}$ ratio averaging 1.8 indicating high effect of hydrothermal solution. Also, the presence of amazonite K-feldspar tends to enhance the content of $\mathrm{Pb}, \mathrm{U}$ and $\mathrm{Th}$. The accessory minerals such as zircon, Ce-monazite, allanite, xenotim, smmarskite and columbite as well as thorianite, thorite, uranothorite and as autunite are main sources of the potential radioactivity in the studied pegmatites.

\section{Conclusion}

The mineralized zoned pegmatites of Abu Rusheid area are trending NNW-SSE and dipping $10-30^{\circ}$ due WSW. The mineralized zoned pegmatite boudins are parallel to the banding in the cataclastic rocks. The distinct variation in major elements content reflects the mineralogical composition of the different zone. On the other hand, the variations of the trace elements, REE in pegmatitic zones reflect the distribution of the economic accessory rare-metal minerals in the pegmatite.

The geochemical data indicate that these pegmatites are enriched in $\mathrm{SiO}_{2}>70 \%$, alkalies, $\mathrm{Rb}, \mathrm{Ag}, \mathrm{Li}, \mathrm{Z}, \mathrm{U}, \mathrm{Th}, \mathrm{Zn}, \mathrm{Pb}, \mathrm{Nb}$ and $\mathrm{FeO} / \mathrm{Mgo}$ ratio but strongly depleted in $\mathrm{CaO}, \mathrm{Sr}, \mathrm{MgO}, \mathrm{Cs}, \mathrm{Cu}, \mathrm{As}, \mathrm{W}$, Co and $\mathrm{Ni}$. They can be considered as rare metal pegmatite class. Abu Rusheid rare earth pegmatite is a mixed (LCT + NYF) family displaying NYF $>>$ LCT characteristics which is marked by $\mathrm{Nb}>\mathrm{Ta}, \mathrm{Y}, \mathrm{Zr}, \mathrm{U}$, Th and REE signature. The LCT-type suit is derived from non depleted upper-crustal lithological suffering of first anatectic event which mobilizes the most volatile component into low-temperature, low-percentage melts.

The present NYF-type pegmatites are characterized by high $\mathrm{F}$, $\mathrm{FeO} / \mathrm{MgO}$ ratio, and high/ economic concentration of $\mathrm{Nb}, \mathrm{Y}, \mathrm{Zr}, \mathrm{Th}, \mathrm{U}$, REE (except $\mathrm{Eu}$ ), where $\mathrm{F}$ plays a critical role in its development. In presence of F, many high field strength elements (HFSE) behave incompatibly and are thus strongly concentrated in highly differentiated NYF -type pegmatite in phases such as zircon, rutile, columbitetantalite, samarskite and other REE mineral 
The studied pegmatites are subalkaline, peraluminous. They are restricted to post-orogentic tectonic setting. Hydrothermal alteration during post-magmatic stages is also identified through the development of a M-type tetrad effect in the REE pattern of pegmatite. The distinct behavior of the most popular isovalent elements ratio $(\mathrm{Zr} / \mathrm{Hf}, \mathrm{Nb} / \mathrm{Ta}$, $\mathrm{Th} / \mathrm{U}, \mathrm{Y} / \mathrm{Ho}$ ) during hydrothermal alteration seems to be non-chondritic and is no longer exclusive the control of ionic radius and charge.

Radioactivity of the studied pegmatite is attributed to plenty of zircon, monazite, allanite, xenotime, fluorite, columbite, sammarskite, thorianite, uranothorite, thorite, autunite and iron oxides. The Abu Rusheid pegmatite can be considered as an economic target for $\mathrm{U}$, Th and other important rare metals.

\section{Acknowledgements}

The authors are deeply indebted to A.A. El Kammar, Geology Department, Cairo University and M. E. Ibrahim, Head of Research Sector, Nuclear Materials Authority, Cairo, for their valuable assistance and critical review of the initial manuscript.

\section{References}

Abd El Wahed, A.A., Sadek, A.A., Abdel Kader, Z.Y. Motomura and K Watanabe (2007) Petrogenetic relationships between pegmatite and granite based on chemistry of muscovite in pegmatite wall zones, wadi El Falio, central Eastern Desert. Annals Geo. Surv. Egypt XXIX:123-134.

Abd El-Naby H.H. and Saleh G.M. (2003) Radioelement distributions in the Proterozoic granites and associated pegmatites of Gabal El Fereyid area, Southeastern Desert, Egypt (J). Applied Radiation and Isotopes 59: 289-299.

Abd El-Naby H.H. and Frish, W. (2006) Geochemical constraints from the Hafafit Metamorphic complex (HMC):evidence of Neoproterozoic back-arc basin development in the central Eastern Desert of Egypt. Journal of African Earth Sciences 45:173-186.

Abdalla, H.M., Ishihara, S., Matsueda, H. and Abdel Monem, A.A. (1998) On the albiteenriched granitoids at um Ara area, southeastern Desert. Paper submitted to the 17th international chemical exploration symposium, Special Issue of J. Geochem. Explor.

Abdel Monem, A. A. and Hurley, P. M. (1979) U - Pb dating of zircons from psammitic gneisses, Wadi Abu Rusheid - Wadi Sikait area, Egypt. Inst. Appl. Geol., Jeddah 3, ( 2): $165-170$.

Adam, J.W. Arengi, J.T. and Parrish,I.S. (1980) Uranium and thorium bearing pegmatites of United States. Derry, Michener and Booth, Inc.Golden, Colorado 80401, 144p.

Allen, G.C., Tempest, P.A. and Tyler, J.W. (1982) Coordinatic model for the defect structure of hyper-stochiometric $\mathrm{UO}_{2}{ }^{2+}{ }_{x}$ and $\mathrm{U}_{4} \mathrm{O}_{9}$. Nature 295: 48-49.

Anders, E. and Grevesse, N. (1989) Abundances of the elements: meteortic and solar. Geochim. Cosmochim. Acta 53: 197-214.

Bau, M. (1997) The lanthanide tetrad effect in highly evolved felsic igneous rocks-a reply to the comment by Y. Pan. Contrib. Mineral. Petrol. 128: 409-412. 
Bau, M. (1999) Scavenging of dissolved yttrium and rare earths by precipitating iron oxyhydroxide: Experimental evidence for $\mathrm{Ce}$ oxidation, Y-Ho fractionation, and lanthanide tetrad effect. Geochim. Cosmochim. Acta 63: 67-77.

Bau, M. (1996) Controls on the fractionation of isovalent trace elements in magmatic and aqueous systems: evidence from $\mathrm{Y} / \mathrm{Ho}, \mathrm{Zr} / \mathrm{Hf}$, and lanthanide tetrad effect. Contrib. Mineral. Petrol. 123: 323-333.

Bau, M., Dulski P. and Mo'ller P. (1995) Yttrium and holmium in South Pacific seawater: Vertical distribution and possible fractionation meachanisms. Chem. Erde 55: 1-15.

Cathelineaus, M. and Holuger, P. (1987) Polyphase metallogenesis of hydrothermal map uranium viens from the southern Armorican massife, France. Proc. Int. Mtg, Nacy, p. 212217.

Cerny, P. (1991b) Rare-element granitic pegmatities. Part I: Anatomy and internal evolution of pegmatitie deposits. Geoscience Canada 18 (2): 49-67.

Cerny, P. and Ercit T.S. (1989) Mineralogy of niobium and tantalum: Crystal chemical relationships, paragenetic aspects and their economic implications. In: Moller, P., Cerny, P. and Saupe, F. (eds.) Lanthanides, Tantalum and Niodium (M). Springer-Verlag, New York, pp. 27-79.

Cerny, P., Ercit, T.S. and Wise, M.A. (1992) The tantalite-tapiolite gap; natural assemblages versus experimental data. Can. Mineral. 30: 587-596.

Collins, L.G. (1996) Origin of mermykite and metasomatic granites (8 parts). Internet home page of http://www.E,005/revised 1.HTM.

Cuney, M. and Friedrich M. (1987) Physicochemical and crystal chemical controls on accessory mineral paragenesis in granitoid : Implications for uranium metallogenesis. Bull. Mineral. 110: 235-247.

Dipak, C.P., Biswajit M. and Heinz J.B. (2006) Mineralogy and geochemistry of pegmatitehosted $\mathrm{Sn}-\mathrm{Ta}-\mathrm{Nb}$ and $\mathrm{Zr}$-Hlf-bearing mineals from the southeaster part of the BasterMalkangiri pegmatite belt, Central India. Ore Geology Reviews 26: 324-342.

El-Kammar,A.A., and El-Mahdi, I.A (2002) Changes occurring in accessory minerals during alkali-metasomatism of granites from Egypt: an environmental scanning electron microscope Study. Egyptian Journal of Geology, pp.173.

EL-Mahdi, I.A. (2008) Preliminary study on zircon from the mylonitic rocks of Abu Rusheid area, Eastern Desert, Egypt. Journal of the faculty education, Zagazig University 6.

Ercit, T.S. (2005) REE-enriched granitic pegmatities. In: Linnen, R.L. and Samson, I.M. (eds.) Rare-element Geochemistry and Ore Deposits. Geological Association of Canala Short Course Notes 17: 257-296.

Friedrich, M. Cuney. M and Poty, B. (1987) Uranium geochemistry in peraluminous leucogranites. Uranium 3: 353-385.

Hassan, M.A. (1973) Geology and geochemistry of radioactive columbite-bearing psammitic gneiss of Wadi Abu Rusheid. South Eastern Desert, Egypt. Annals of Geol. Surv. Egypt., V. III, 207-225 p.

Hilmy M.E., EL Bayoumi R.M., and Eid A. S. (1990) Geology, geochemistry and mineralization of the psammitic gneiss of Wadi Abu-Rusheid, Eastern Desert, Egypt. Journal of African Earth Sciences 2:197-205.

Henderson, C.M.B. and Martin J.S. (1989) Compositional relation in Li-micas from SW England and France :An ion-electron microprobe study. Miner. Mag. 53: 427-449.

Ibrahim, M. E., Abd El-Wahed, A. A., Rashed, M. A., Khaleal, F. M. 1, Mansour, G. M. and Watanabe, K. (2007) Comparative study between alkaline and calc-alkaline lamprophyres, Abu Rusheid area, south Eastern Desert, Egypt. The 10th Inter. Min., Petrol., and Metall. Eng. Conf., Assuit univ., 99-115.

Ibrahim, M. E., El Tokhi, M. M., Saleh G. M. and Rashed, M. A. (2006) Lamprophyre bearing-REEs, South Eastern Desert, Egypt. 7th Intern. Conf. on Geochemistry, Fac. Sci., Alex. Univ., Alex., Egypt, 6-7 Sept.. 
Ibrahim, M.E., Saleh, G. M., Hassan, M. A., El-Tokhi, M. M. and Rashed, M. A. (2007b) Geochemistry of lamprophyres bearing uranium mineralization, Abu Rusheid area, south Eastern Desert, Egypt. The 10th Inter. Min., Petrol., and Metall. Eng. Conf., Assuit univ., 41-55.

Ibrahim, M., Saleh G., Rashed M. and Watanabe, K. (2007c) Base metal mineralization in lamprophyre dykes at Abu Rusheid area, south Eastern Desert, Egypt. The 10th Inter. Min. Petrol., and Metall. Eng. Conf., Assuit Univ., 31-40.

Ibrahim, M.E. (1999) On the Occurrence of U, REE-bearing samarskite, Abu Dob area, Central Eastern Desert, Egypt. Proc. Egypt. Aca. Sci. 49.

Irber, M.E.W. (1999) The lanthanide tetrad effect and its correlation with $\mathrm{K} / \mathrm{Rb}, \mathrm{Eu} / \mathrm{Eu}$, $\mathrm{Sr} / \mathrm{Eu}$, $\mathrm{Y} / \mathrm{Ho}$, and $\mathrm{Zr} / \mathrm{Hf}$ of evolving peraluminous granite suites. Gechim. Cosmochim. Acta $\mathbf{6 3}$ : 489-508.

Irvine, T.N. and Boragar, W.R.A. (1971) A guid to the classification of the common volcanic rocks. Can, J. Earth Sci. 8: 523-548.

Kawabe, I. (1995) Tetrad effects and fine structures of REE abundance patterns of granitic and rhyolitic rocks: ICP-AES determinations of REE and Y in eight GSJ reference rocks. Geochem. J. 29: 213-230.

Kostov, I. (1977) Crystalochemical differentiation and localization of uranium are deposits in the earth crust. IAEA, Vienna-TC-25/2 Session I. Recognition and Evaluation of Uranium Area, 15-33.

Linnen, R.L. (1998) Experimental constraints on the association of $\mathrm{Li}$ with $\mathrm{Ta}$ in granitic pegmatites. Abstract and programme, $17^{\text {th }}$ General Meeting IMA, August, Toronto, p. A146.

London D. (1992) The application of experimental petrology to the genesis and crystallization of granitic pegmatites. Canadian Mineralogist. 30: 499-450.

Masuda, A. and Akagi, T. (1989) Lanthanide tetrad effect observed in leucogranites from China. Geochem. J. 23: 245-253.

Masuda, A., Kawakami, O., Dohmoto, Y. and Takenaka, T. (1987) Lanthanide tetrad effects in nature: two mutually opposite types, W and M. Geochem. J. 21: 119-124.

Moller, P. (1998) Eu anomalies in hydrothermal minerals: Kinetic versus thermodynamic interpretation (abstract). In: Hagni, R.D. proceeding of the Ninth Quadrennial IAGOD symposium, schweizer, bart'sche Verlagsbuchhandlung, pp. 239-246.

Moller, P. and Muecke, G.K. (1984) Significance of europium anomalies in silicate melts and crystal-melt equilibria: a re-evaluation. Contrib. Mineral. Petrol. 87: 242-250.

Monecke, T., Kempe, U., Monecke, J., Sala, M. and Wolf, D. (2002) Tetrad effect in rare earch element distribution patterns: a method of quantification with application to rock and mineral samples from granite-related rare metal deposits. Geochim. Cosmochim. Acta 66: 1185-1196.

Monecke, T., Monecke, J., Monch, W. and Kempe, U. (2000) Mathematical analysis of rare earth element patterns of fluorites from the Ehrenfriedersdorf tin deposit, Germany: evidence for a hydrothermal mixing process of lanthanides from two different sources. Mineral. Petrol. 70: 235-256.

Montel I.M. (1985) Is monazite guilty? Experimental determination of Ce-monazite solubility in $\mathrm{Na}_{2} \mathrm{O}, \mathrm{K}_{2} \mathrm{O}, \mathrm{SiO}_{2}$ and $\mathrm{Al}_{2} \mathrm{O}_{3}$ melts. Terra Congita 5 (2-3): 33 .

Morteani G., Preinfalk C., Spiegel W. and Bonalumi A. (1995) The Achala granitic complex and the pegmatites of the Sierras Pampeanas (Northwest Argentina): A study of differentiation. Economic Geology 90: 636-647.

Naito, K., Jsuji, T. and Amtsui, T. (1989) Defect structure and the related properties of $\mathrm{UO}_{2}$. In: Nowtny, J. and Weppner, W. (eds.) Non-Stoichiometric compounds. Naito advances workshop, KL uwer, Dordrecht, 27-44.

Pagel, M. (1982) The mineralogy and geochemistry of uranium, thorium and rare elements in two radioactive granites of Vosages, France. Min, Mag. 46/339: 149-161. 
Parnell, I. (1989) Uranium-rich xenotime in bitumen, moonto mines, south Australia. Australian Mineralogist 4 (4): 145-148.

Petro, W.L., Vogel, T.A. and Wilband, J.T. (1979) Major clements chemistry of plutonic rock suites from compressional and extensional plate boundaries. Chem. Geol. 26: 217-235.

Recio, C., Fallick, A.E., ugidos, J.M. and stephens, W.E. (1997) Characterization of multiple fluid-granite interaction pro cesses in the episyenite of Avila -Bejar central Ibeiam Massif, spain. Chemical Geology 143: 127-144.

Saleh. M.G., El Galy, M.M. and Obeid, M.A. (2007) Geochemical characteristics and spectrometric prospecting in the muscovite-bearing pegmatites and granites, southeastern Aswan, Egypt. Chin. J. Geochem. 27: 9-20.

Schroll, E. (1976) Analytische Geochemie. II 374p; Stuttgart, Enke.

Shand, S.J. (1951) Eruptive Rocks. John Wiely, New York.

Simmons, W., Karen L.Webber, Alexander U. Falster and James W. Nizamoff (2003) Pegmatology: pegmatite mineralogy, petrology and petrogenesis, department of geology and geophysics. Rubellite Press/Karen L. Webber, 176p.

Simmov, S.D. (1984) U-Th-RE mobility in granitic environments at the hydrothermal stage. IAEA, Vienna, 215-246.

Sosa G.M., Augshurger M.S. and Pedregosa J. (2002) Columbite-group minerals from rare metal granitic pegmatities of the Sierra de San Luis, Argentina. European Journal of Mineralogy 14: 627-636.

Suror, A.A., Omar, S.A. and Zunic, T.B. (2004) Cation ordering and chemistry of cryptically zoned columbite from Ras Baroud rare-metal pegmatites, Central Eastern Desert, Egypt. 6th International Conference On Geochemistry, Alexandria University, Egypt, 777-795.

Takahashi, Y., Yoshida, H., Sato, N., Hama, K., Yusa, Y. and Shimizu, H. (2002) W- and Mtype tetrad effects in REE patterns for water-rock systems in the Tono uranium deposit, central Japan. Chem. Geol. 184: 311-335.

Taylor, S.R. and Mclennan, S.M. (1985) The Continental Crust ; its composition and evolution. BlackWell, Oxford.

Tischendorf, G. (1977) Geochemical and petrographic characteristics of silicic magmatic rocks associated with rare element mineralization. In: Stemprok, M., Burnol, L., and Tischendorf, G. (eds.) Symposium, Metallization Associated with Acid Magmatism (MAWAM). Prague Geological Survey, v. 2, p. 41-96.

Voloshin, A.V. (1989) Mineralization of rare metals and rare earths in Proterozoic Randpegmatites. Precambrian Granitoids. Conf. Abst., Helsinki, 141p.

Wades, J. and Wood B.J. (2001) The earth's "missing" niobium may be in the core. Nature 409: 75-78.

Wang, R.C., Zhao, G.T., Lu, J.J., Chen, X.M., XU, S.J. and Wang, D.Z. (2000) Chemistry of Hf-rich zircon from the loashan I- and A-type granites, Eastern China. Mineral-Magaz. 64 (5): 867-877.

Weyer, S., Munker, C. Rehkamper, M. and Mezger, K. (2002) Determination of ultra-low Nb, $\mathrm{Ta}$, and $\mathrm{Hf}$ coneentrations and the chondritc $\mathrm{Zr} / \mathrm{Hf}$ and $\mathrm{Nb} / \mathrm{Ta}$ rations by isotope dilution analyses with multiple collector ICP-MS. Chmical Geology 187 (3-4): 295-313.

Wise, M.A. and Cerny, P. (1996) The crystal chemistry of tapiolite series. Canadian Mineralogist 34: 631-647.

Zagorsky V.Y. and Peretyazhko I.S. (2006) The Malkhan granite-pegmatite system: intrusion of chemically heterogenous pegmatite magma. Goldschmidt Conference Abstracts, pp.A729. 


\section{الخواص الكيميائية والإشعاعية للبجماتيت المتمعدن من منطقة أبو رشيد جنوب الصحراء الثرقية}

\section{عبلة أحمد على رجب}

هيئة الدواد النوية، القطامية، جمهورية دصر العربية

المستخلص. تم تحليل البجماتيـت المتمعدن في منطقـة أبو رشيد بواسطة مطياف الكتلة البلازمسي لتحديد محتوى العناصـر الرئيسية والثـحيحة والنـادرة. ويضـرب البجماتيت المتمعدن في اتجـاه شمال

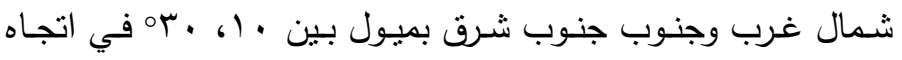
غرب جنوب غرب ويتداخل موازياً للتورق في الصخور الحاوية عليه.

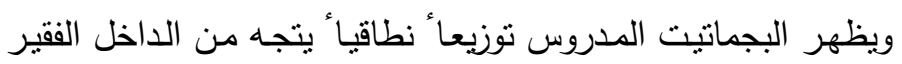

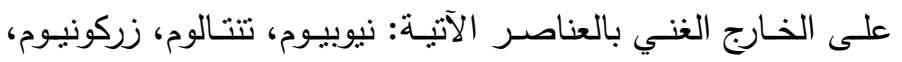

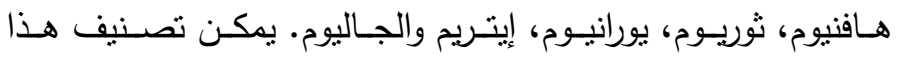

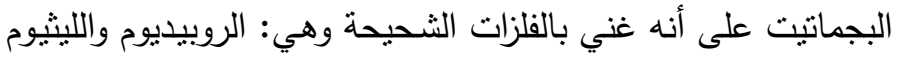

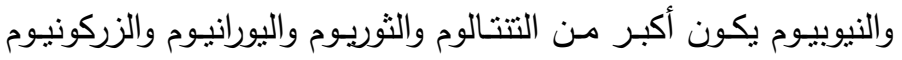

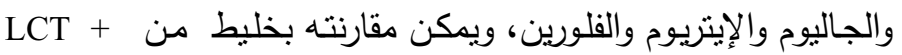
NYF مظهرا خواص NYF أكبر من LCT، ويحتوي هذا البجماتيت على معادن غنية بالفلزات النادرة من الزركون والروتيل والكولمبيت

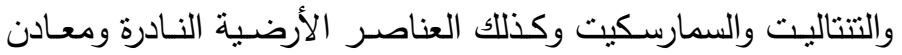
الثوريوم، كذلك تم اكتشاف بعض المعادن الثنانوية لليورانيوم. وتتمثل المعادن الإضافية بالكاستيريت والفلوريت البنفسجي الغامق والكالسيت والجيوتيت والهيماتيت والبيريت والماجنيتيت والزنفيلدايت والفلوجوبيت بايت

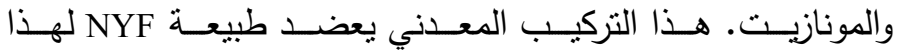
البجماتيت. وهذا البجماتيت المدروس بين الألواح عالي التميز من لن لئن 
نوع NYF ويتمـايز بنسبة عالية من FeO/MgO وتركيز عـالي من النيوبيوم والإيتريم والزركونيوم والثوريوم واليورانيوم والجاليوم والعناصر

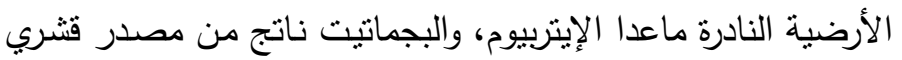
بيرونيروزوي عال بالفلورين وفقير في السيزيوم والبورون والفوسفور .

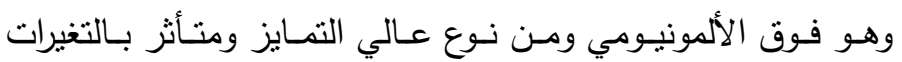
الناتجة من المحاليل الحارة.

M-type من بظهر هذا البجماتيت ظاهرة Tetrad effect مع زيادة نسبة Y/Ho و Nb/Zr مصاحبة بزيادة محتوى SiO Rb/Sr اليورانيوم والثثريوم الموجود في كل من معادن اليورارنيوم (الأتونيت)

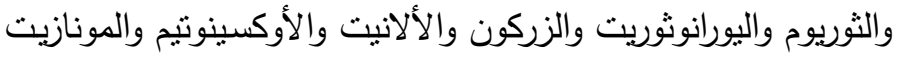

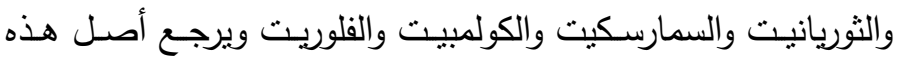
الثاذة الإشعاعية إلى كل من العوامل الصهيرية والحرمائية. 